\title{
Herpes Virus Fusion and Entry: A Story with Many Characters
}

\author{
Roselyn J. Eisenberg ${ }^{1, *}$, Doina Atanasiu ${ }^{2}$, Tina M. Cairns ${ }^{2}$, John R. Gallagher ${ }^{2}$, \\ Claude Krummenacher ${ }^{2}$ and Gary H. Cohen ${ }^{2}$
}

1 Department of Pathobiology, School of Veterinary Medicine, University of Pennsylvania, Philadelphia, PA 19104, USA

2 School of Dental Medicine, University of Pennsylvania, 240 South 40th Street, Philadelphia, PA 19104, USA; E-Mails: doinaa2@biochem.dental.upenn.edu (D.A.); tmcairns@biochem.dental.upenn.edu (T.M.C.); joga@dental.upenn.edu (J.R.G.); ckrummen@dental.upenn.edu (C.K.); ghc@dental.upenn.edu (G.H.C.)

* Author to whom correspondence should be addressed; E-Mail: roselyn@dental.upenn.edu; Tel.: +1-215-898-6552; Fax: +1-215-898-8385.

Received: 25 April 2012; in revised form: 4 May 2012 / Accepted: 9 May 2012 /

Published: 10 May 2012

\begin{abstract}
Herpesviridae comprise a large family of enveloped DNA viruses all of whom employ orthologs of the same three glycoproteins, $\mathrm{gB}, \mathrm{gH}$ and gL. Additionally, herpesviruses often employ accessory proteins to bind receptors and/or bind the heterodimer $\mathrm{gH} / \mathrm{gL}$ or even to determine cell tropism. Sorting out how these proteins function has been resolved to a large extent by structural biology coupled with supporting biochemical and biologic evidence. Together with the $G$ protein of vesicular stomatitis virus, $\mathrm{gB}$ is a charter member of the Class III fusion proteins. Unlike VSV G, gB only functions when partnered with $\mathrm{gH} / \mathrm{gL}$. However, $\mathrm{gH} / \mathrm{gL}$ does not resemble any known viral fusion protein and there is evidence that its function is to upregulate the fusogenic activity of $\mathrm{gB}$. In the case of herpes simplex virus, $\mathrm{gH} / \mathrm{gL}$ itself is upregulated into an active state by the conformational change that occurs when $\mathrm{gD}$, the receptor binding protein, binds one of its receptors. In this review we focus primarily on prototypes of the three subfamilies of herpesviruses. We will present our model for how herpes simplex virus (HSV) regulates fusion in series of highly regulated steps. Our model highlights what is known and also provides a framework to address mechanistic questions about fusion by HSV and herpesviruses in general.
\end{abstract}


Keywords: glycoproteins; HSV; CMV; EBV; VZV; crystal structure; functional region; monoclonal antibody

\section{Introduction}

Virus-cell fusion induced by enveloped viruses requires disruption of both the inner and outer layers of cellular and viral membranes. For many enveloped viruses, binding of a single surface glycoprotein to its receptor promotes $\mathrm{pH}$-dependent conformational changes once within the acidic environment of an endosome, thereby bringing the viral bilayer in proximity with the host cell membrane to promote fusion. Herpesvirus entry and membrane fusion require three virion glycoproteins, $\mathrm{gB}$ and a $\mathrm{gH} / \mathrm{gL}$ heterodimer, that function as the "core fusion machinery" [1-10] (Figure 1).

Figure 1. Fusion machinery of herpesviruses. All herpesviruses utilize gB and gHgL for membrane fusion. Different herpesviruses have different accessory proteins involved in regulation of membrane fusion. $\mathrm{gD}$ is used by alpha herpes viruses (HSV), and porcine herpesvirus (PRV) uses gp50. Beta herpesviruses (HCMV) use UL128, UL130, and UL131. Gamma herpesviruses (EBV) use accessory protein gp42. The only structures that are currently known can be accessed from the PDB database: HSV-1 gB, 2GUM; HSV-2 gHgL, 3M1C; HSV-1 gD, 2C36; EBV gB, 3FVC; EBV gHgL, 3PHF; EBV gp42, 3FD4; PRV gH, 2XQY.

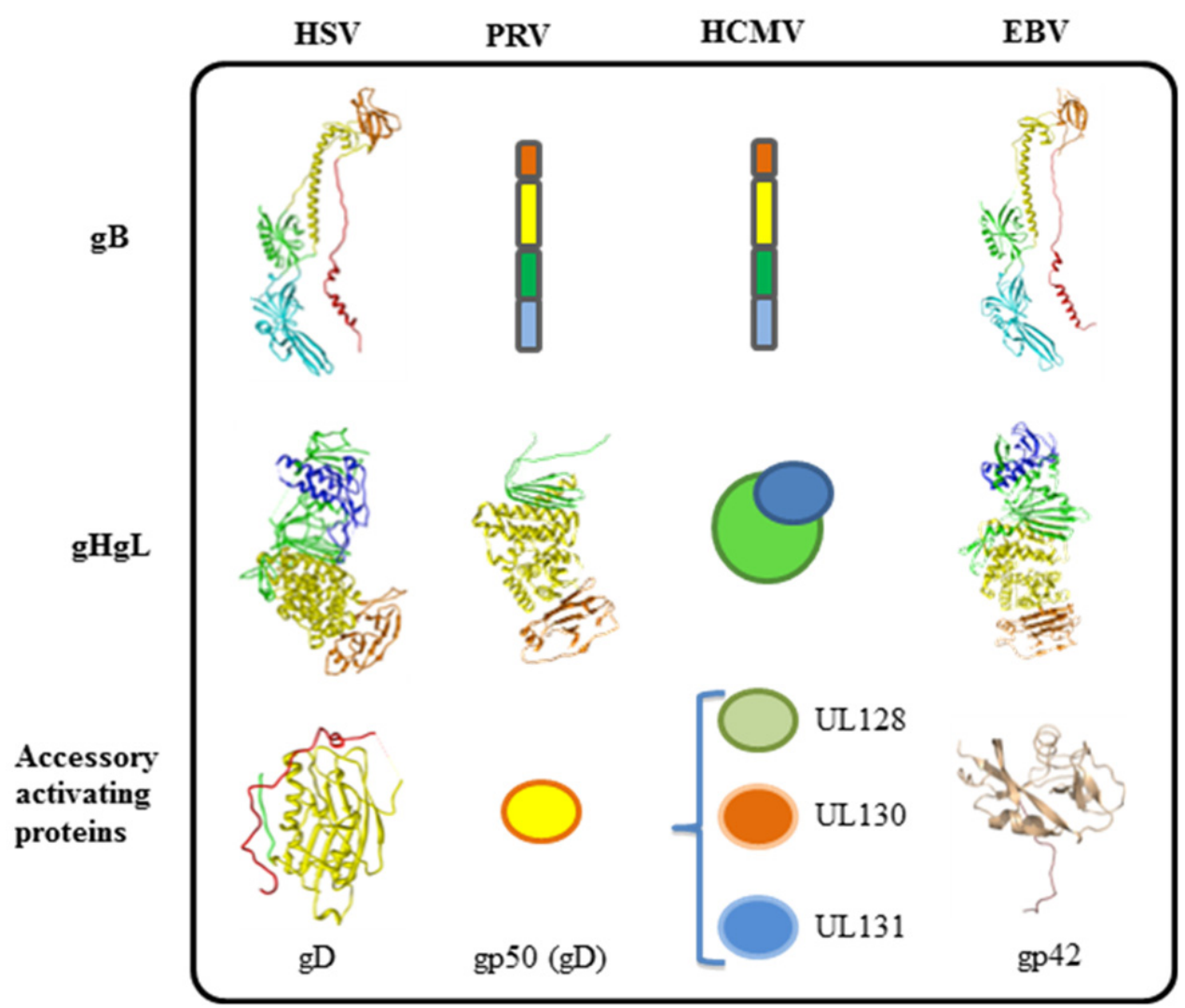


A number of reports have shown that herpesviruses require additional accessory proteins to provide tropism and/or to trigger the core fusion machinery for virus entry and cell-cell fusion (Figure 1). Some examples include human cytomegalovirus (HCMV), UL128, 130 and 131 (abbreviated UL128-131) interact with $\mathrm{gH} / \mathrm{gL}$, which enables the virus to enter epithelial and endothelial cells [11] as opposed to fibroblasts but an entry receptor has not firmly been defined for CMV. In contrast, HSV can interact with two different protein receptors for entry, HVEM and nectin-1 (Figure 2) [12].

Figure 2. Fusion machinery of HSV. The minimal set of proteins required for HSV membrane fusion is depicted to scale. $\mathrm{gB}$ is structurally conserved across all herpesviruses, while $\mathrm{gH} / \mathrm{gL}$ is more variable. $\mathrm{gD}$ is the accessory fusion protein required for membrane fusion in HSV. gD determines cell tropism by binding cellular receptors HVEM or Nectin-1. All proteins are colored according to their structural regions, as defined previously for HSV gD, HSV gH/gL, HSV gB, HVEM and Nectin-1.

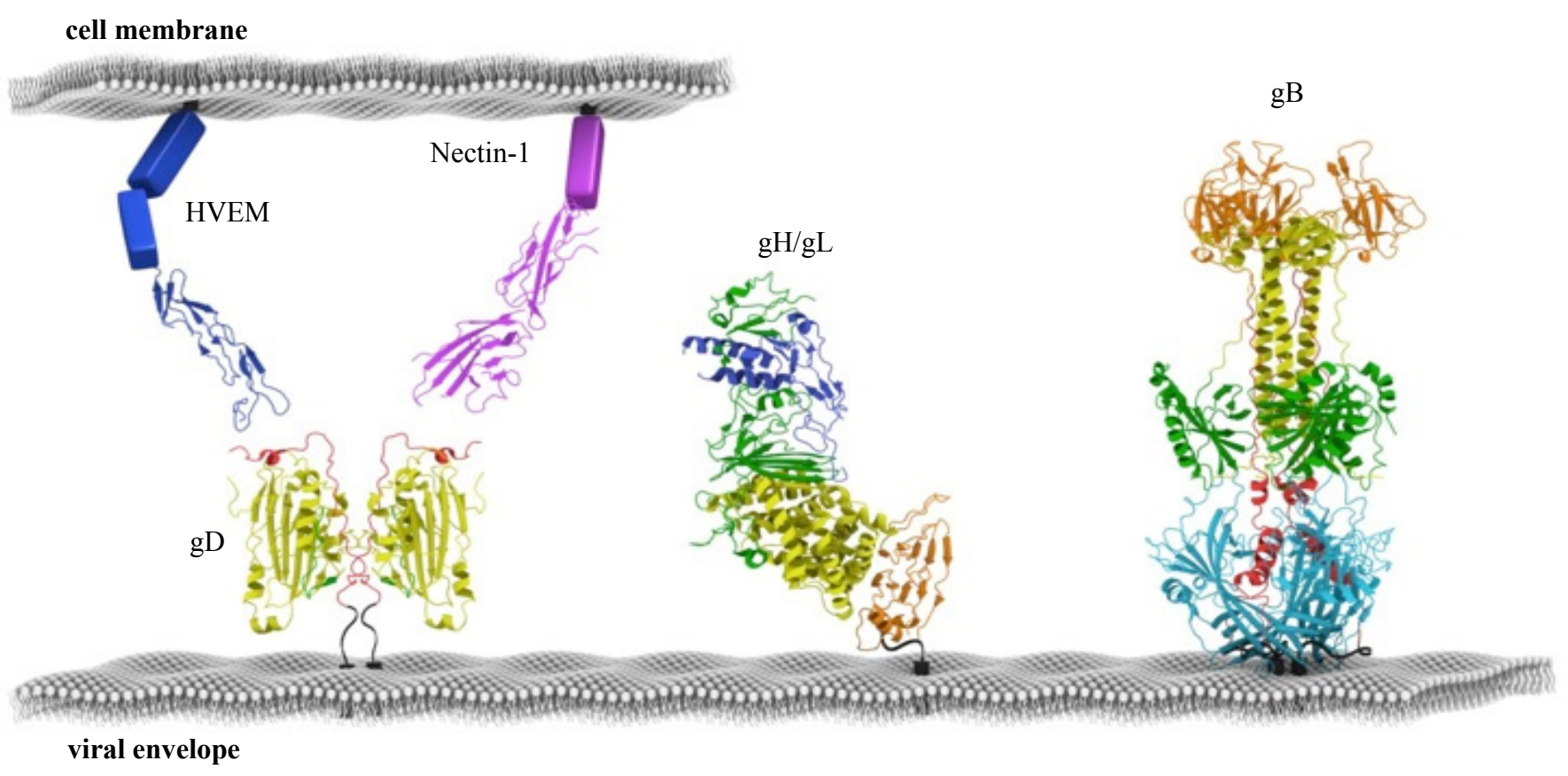

Both of these proteins bind to $\mathrm{gD}$, the principal entry receptor of herpes simplex virus (HSV). It is of some interest that the related alphaherpesvirus, pseudorabies virus (PRV), cannot use HVEM but can use nectin-1 as a gD receptor. In the case of Epstein Barr Virus (EBV), gp42 binds to a specific cell receptor, human leucocyte antigen (HLA), which is present on B cells but not on epithelial cells, and this difference determines virus tropism $[13,14]$. $\mathrm{gH} / \mathrm{gL}$ binds integrins alpha, beta 6 or 8 on epithelial cells as a regulator for fusion $[15,16]$. Another gamma herpesvirus, HHV8 interacts with the receptor for ephrine A2 to amplify signals needed for infection. There are many other examples where the entry machinery of herpes viruses up-regulate signal cascades and the following references represent a sampling: [17-20]. Our goal in this review is to emphasize our current view of the mechanistic basis for entry and cell-cell fusion by herpesviruses and how it might affect cell tropism where that has been demonstrated. Finally, we will offer our view of how HSV in particular uses four glycoproteins and a cell receptor to carry out cell-cell fusion and virus entry. 


\section{The Two Receptors of HSV and Their Roles in Entry and in vivo Tropism}

Proteins associated with the core fusion machinery play an important role in virus tropism, for instance through receptor selection. Clinical isolates of both HSV-1 and HSV-2 have the ability to use both HVEM and nectin-1 as entry receptors that bind gD, regardless of what type of lesion they came from [21], suggesting that both receptors may play important roles in vivo. As HVEM is a TNFR-like receptor primarily found on immune cells, its role as a viral entry receptor for all strains of HSV tested remains somewhat puzzling, as T cells are not targets of productive HSV infection in vivo. However, the interaction may be important for modulating the host's T-cell response to ensure survival of the virus and possibly prevent unchecked replication. For example, it has been shown that gD competes with BTLA, an HVEM ligand that reduces HVEM expression on the T-cell surface [22,23]. This competition is due to the fact that both $\mathrm{gD}$ and BTLA bind to most of the same residues on HVEM. Thus, HSV gD may interfere with a delicate immune balance that normally occurs in the host.

In contrast, nectin-1 is a cell adhesion molecule found abundantly on epithelial cells and at neuronal synapses [24,25], known targets for infection. Thus, its role in promoting viral replication is more apparent. Experiments using monoclonal antibodies (MAbs) to either nectin-1 or HVEM to block receptor usage in murine and human neurons showed that nectin-1 is the preferred receptor in the ultimate targets of HSV-1 in vivo [26,27]. Other studies to address this issue used mice knocked out for either HVEM, nectin-1, or both. When knockout mice lacking nectin-1 were infected intra-vaginally with HSV-2, the virus failed to spread to sensory ganglia [28,29]. Experiments with mice lacking either nectin-1 or HVEM showed that nectin-1 is essential for HSV-1 infection via the intracranial route and for encephalitis HVEM is largely "irrelevant". However, recent studies showed that although nectin-1 was more important as an entry receptor into cornea, mice knocked out for both HVEM and nectin-1 were not susceptible to corneal infection by HSV-1 [30]. These results suggest that both receptors play a role in HSV entry in vivo, but that the balance is tilted towards nectin- 1 . It is interesting that at least in in vitro studies, nectin-1 can act as an entry receptor for PRV, bovine herpesvirus-1 (BHV-1) and B virus [31-34]. This widespread use of nectin-1 and perhaps other nectin family members may be related to how these viruses have evolved with their specific hosts.

One exception to this widespread use of $\mathrm{gD}$ and nectins by alphaherpesviruses is VZV which does not have a gD gene and hence cannot use either HVEM or one of the nectins for entry. Indeed, it is still somewhat mysterious which glycoprotein functions as the receptor binding protein for VZV, although there is mounting evidence that this function is assumed by glycoprotein $\mathrm{gE}[35,36]$. Furthermore, there is evidence that insulin degrading enzyme (IDE) binding to VZV gE is required for infection in an in vitro system, and acts as a receptor for spread of the virus from cell to cell $[36,37]$. However, in a SCID-human model of human pathogenesis, where human cells are grafted onto SCID mice and then infected, the experiments suggest that the interaction between $\mathrm{gE}$ and cellular IDE is dispensable for VZV infection of the dorsal root ganglia [38]. This illustrates how important it is to relate in vitro studies to the in vivo situation. Perhaps future experiments will identify an additional receptor that is used by VZV in both systems. 


\section{Tropism of Herpesviruses is Often Defined by Accessory Receptor Binding Proteins and Receptors}

For many years, a puzzling observation about HCMV entry was that standard or laboratory strains of the virus (such as Towne or AD169) could readily infect fibroblasts but not epithelial or endothelial cells, the major target cells of this virus in vivo. However, sequencing of fresh clinical isolates of the virus revealed that they contains a large number of genes that were missing in the laboratory strains [39]. Among these were genes for three glycoproteins, UL128,130 and 131 (UL128-131) which are now known to be accessory proteins that bind $\mathrm{gH} / \mathrm{gL}$ for infection of epithelial and endothelial cells (Figure 1) [11,40,41]. These clinical isolates were able to infect epithelial cells but not fibroblasts. In contrast, another HCMV glycoprotein, gO, which was shown to co-associate with $\mathrm{gH} / \mathrm{gL}$, was originally thought to be a $\mathrm{gH} / \mathrm{gL}$ accessory protein but was more recently shown to act more like a $\mathrm{gH} / \mathrm{gL}$ chaperone $[42,43]$. Thus, the pentameric complex defines tropism for HCMV into epithelial and endothelial cells but the presence of UL128-131 makes the virus refractory for entry into fibroblasts. In fibroblasts it appears that only $\mathrm{gH} / \mathrm{gL}$ and $\mathrm{gB}$ are required for virus entry [44], though other accessory proteins may yet be discovered. Interestingly, only $\mathrm{gH} / \mathrm{gL}$ and $\mathrm{gB}$ are needed for in vitro cell-cell fusion of a variety of cell types [8] although an unidentified cellular protein might also be involved in this process, e.g., MHC which is present on target cells [45-47]. On the other hand, gO promotes export of $\mathrm{gH} / \mathrm{gL}$ from the endoplasmic reticulum (ER) of all three cell types and the accumulation of $\mathrm{gH} / \mathrm{gL}$ in the trans-Golgi network [48]. Thus it is needed for proper insertion of $\mathrm{gH} / \mathrm{gL}$ into infectious virions but apparently it is not itself incorporated into the virion. Thus, in HCMV, the presence of UL128-131 in the virion envelope is a determinant of cell tropism, though it is not clear if one of these three proteins binds a cell receptor. Indeed, several receptors have been proposed for HCMV, e.g., epidermal growth factor receptor EGFR and integrins [49].

In the case of HHV6, another betaherpesvirus, glycoproteins gQ1 and gQ2 bind gH/gL and promote the use of CD46 as an entry receptor on cells that express this protein [9,50,51]. Alternatively, a complex of $\mathrm{gH} / \mathrm{gL}$ with another viral protein, $\mathrm{gO}$, does not associate with $\mathrm{CD} 46$ and may allow entry into other cells that express a receptor that has not yet been defined. Again, these proteins may be determinative of which cell type is infected. The common theme is that all of these viruses employ different accessory proteins not just for receptor binding but as tropism factors. Ultrastructural studies may help clarify some of the more mysterious aspects, undoubtedly a goal of many investigators. Clearly, for beta herpesviruses, certain pieces of the entry/fusion/tropism puzzle have not yet fallen into place.

However, what is well understood is a very elegant molecular mechanism that regulates EBV cell tropism both at the level of cell biology [14] and at the ultrastructural level (reviewed in Connolly et al. [4]). Although glycoprotein gp350/220 is needed for EBV attachment, it is now clear that gp42 is the entry receptor-binding protein for EBV [52]. The type II membrane protein gp42 is required for infection of B cells, but not epithelial cells [53]. When EBV infects B cells, gp42 binds the human leukocyte antigen (HLA) (Figure 3E). Importantly, expression of gp42 on the surface of the virion changes as the virus alternates between infection of epithelial cells and lymphocytes in the human host. When the virus is produced in epithelial cells, the virion contains abundant gp42, which allows efficient infection of B cells. Conversely, when the virus is produced in B cells, the amount of gp42 in the virion is reduced, possibly due to being bound to the receptor (HLA). B cells also make a 
truncated soluble form of gp42 that appears to inhibit entry of the virus into epithelial cells. Indeed, EBV fusion with an epithelial cell is initiated by an interaction between several integrins and $\mathrm{gH} / \mathrm{gL}[15,54]$ and gp42 blocks binding of $\mathrm{gH} / \mathrm{gL}$ to integrins [5,16,55]. At the same time, in epithelial cells less gp42 is degraded and the resulting virions have a high gp42 content that targets these virions to B-lymphocytes [56]. It is of interest that $\mathrm{gH} / \mathrm{gL}$ itself appears to play a crucial role in defining cell tropism. It was recently reported that a KGD motif of EBV $\mathrm{gH} / \mathrm{gL}$ may play a role in infection of both $\mathrm{B}$ cells and epithelial cells. The authors feel that this acts as a tropism switch [16], although this is still under debate by others in the EBV field.

Structural analyses and mutagenesis of unbound gp42 and gp42 bound to HLA indicate a conformational change [57-59]. Because gp42 also binds specifically to gH/gL, it is possible that conformational changes that occur when gp42 binds its receptor help position it to bind its $\mathrm{gH} / \mathrm{gL}$ partner [57,58,60,61]. For instance, gp42 contains a hydrophobic pocket that widens in response to HLA binding and it has also been suggested that this widened pocked is "reserved" for a second high affinity $\mathrm{gH} / \mathrm{gL}$ binding site.

\section{Structural Studies of HSV gD and Its Two Protein Receptors}

A major development in our understanding of how HSV gD interacts with its receptors was the determination of the structures of $\mathrm{gD}$ bound to HVEM and more recently to nectin-1 [62-65] (Figures 2 and $3 \mathrm{~A}-\mathrm{C}$ ). The form of $\mathrm{gD}$ used for crystallization of both complexes was truncated at amino acid 285 because of its very high affinity for gD compared with that of longer forms [66-68]. In the gD/HVEM complex (Figure 3A), gD consists of a V-like immunoglobulin ( $\mathrm{IgV}$ ) core that acts as a scaffold for $\mathrm{N}$ - and $\mathrm{C}$-terminal extensions. In this complex, the $\mathrm{N}$-terminus of $\mathrm{gD}$ forms a hairpin structure into which Tyr23 of HVEM inserts, thereby stabilizing the interface [62]. An intermolecular $\beta$-sheet between $\mathrm{gD}$ and the first cysteine-rich domain of HVEM as well as key hydrogen bonds between $\mathrm{gD}$ and the second cysteine-rich domain of HVEM are also important. Mutational analysis of the interface confirmed that Tyr23 of HVEM and gD residues that form the beta sheet with HVEM are critical to maintain the integrity of the complex $[69,70]$. When gD is not liganded to HVEM, the first 21 amino acids are flexible and some are even too disordered to be resolved (Figure 3A) [62]. Thus, HVEM contributes to formation of the more structured hairpin loop at the N-terminus of $\mathrm{gD}$ that is critical for fusion and entry of HSV into cells bearing HVEM [62,63,71]. This conformational change raised the possibility that it accounted for how binding of $\mathrm{gD}$ to either receptor might trigger downstream events, assuming that such a change would be common to binding of both receptors.

Figure 3. Structures of HSV gD and EBV gp42 alone or bound to their ligands. (A) $\mathrm{gD}(285 \mathrm{t})$ bound to HVEM. The $\mathrm{gD}$ Ig fold is shown in yellow and its core extensions are in gray. The N-terminus (aa 1-32 in green) forms a hairpin bent at residue 21 . The first two cysteine-rich domains (CRD) of HVEM are shown as blue ribbons. The essential tyrosine 23, which inserts between the strands of the $\mathrm{gD} \mathrm{N}$-terminal hairpin, is shown in red; (B) $\mathrm{gD}(285 \mathrm{t}$ ) bound to nectin-1. $\mathrm{gD}$ is colored as in $\mathbf{A}$. The $\mathrm{N}$-terminal and C-terminal flexible residues $(1-22,260-285)$ are not solved. The V-domain of nectin-1 is shown as blue ribbons with beta strands $\mathrm{CC}^{\prime} \mathrm{C}$ " that contact $\mathrm{gD}$ shown in red. The essential 
phenylalanine 129 , which inserts into a pocket near the N-terminus of $\mathrm{gD}$ is colored red; (C) Unbound HSV gD306t(307Cys) protomer. $\mathrm{gD}$ is colored as in $\mathbf{A}$ with the C-terminus (269-307) shown as a red ribbon. The C-terminus anchoring residue tryptophane 294 is shown in red and the position of Tyrosine 38 is indicated. The extended N-terminal 22 residues and the flexible hinge (aa. 260-268) are not visible; (D) Unbound EBV gp42 protein is shown in tan and residues at the N-terminus of the solved structure are colored brown (aa 83-93); (E) gp42 bound to human HLA protein. gp42 is colored as in D. The human HLA-DR1 is shown as teal ribbons and the antigenic peptide is colored blue. In all panels $\mathrm{N}$ and $\mathrm{C}$-terminal residues of gD and gp42 are shown when visible. Representations of $\mathrm{gD}$ and gp42 are not drawn to the same scale.
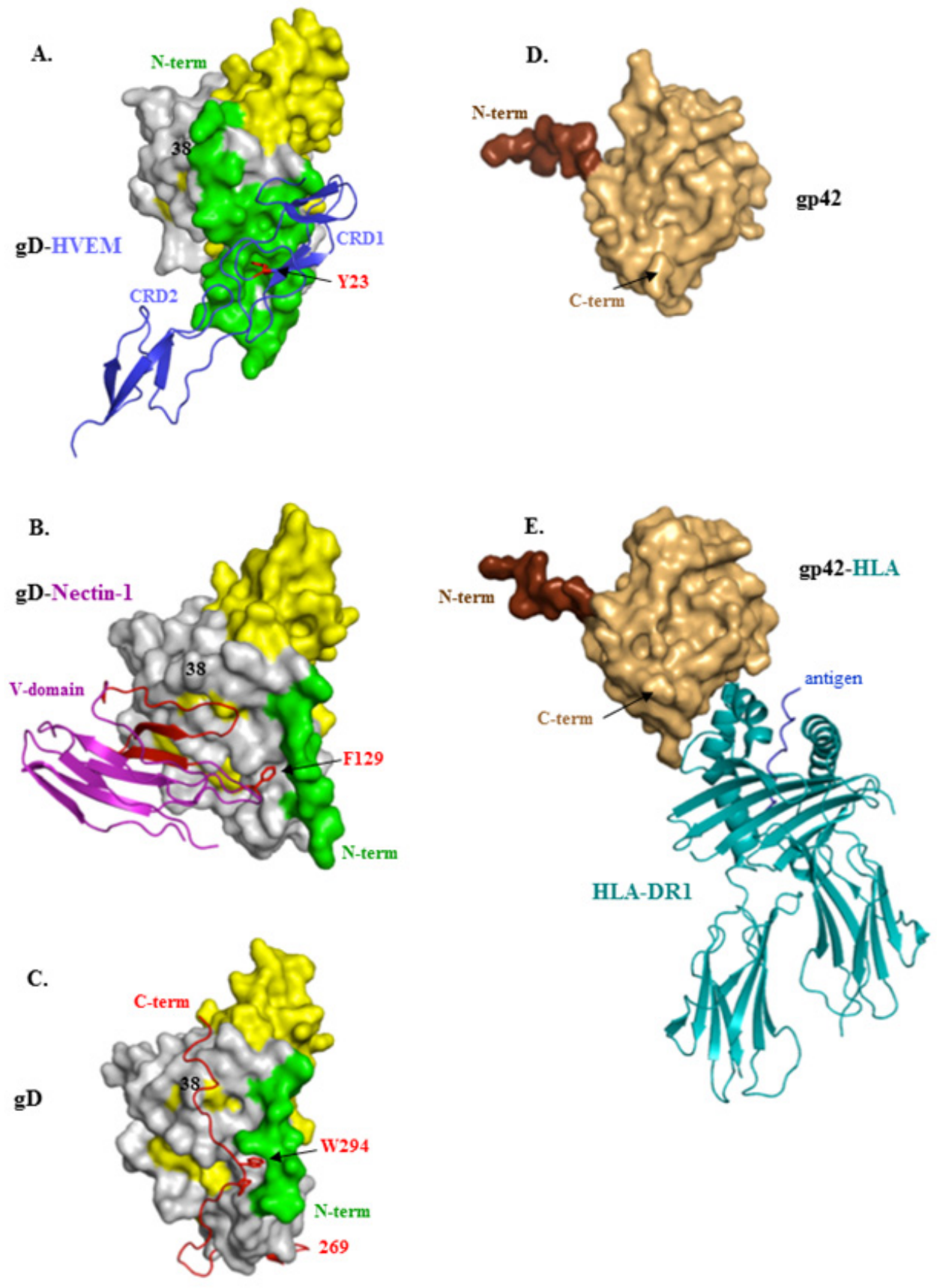
Therefore, we and others mapped the binding of nectin-1 on $\mathrm{gD}$ (and vice versa). The initial studies, done both by mutagenesis and epitope mapping, showed that all of the residues of nectin- 1 involved in $\mathrm{gD}$ binding reside in the distal V-domain of this Ig-like structure [72-74]. When expressed alone, this domain binds to $\mathrm{gD}$ with the same affinity as the full nectin-1 ectodomain [68]. Specific residues within the $\mathrm{V}$-domain that contribute to binding of $\mathrm{gD}$ were also identified [75-79]. Surprisingly, the site on $\mathrm{gD}$ for nectin-1 binding was mapped to residues mostly downstream of the N-terminus that binds HVEM (Figure 3B) [76,77,80-82] and suggested that the N-terminus of gD was not involved in nectin-1 binding. To test this possibility, a mutant was constructed to lock the N-terminal residues of $\mathrm{gD}$ into a hairpin with a disulfide bond between amino acids 3 and 38 (Figure 3C). The gD mutant A3C-Y38C was still able to bind HVEM but was unable to bind nectin-1 [77], suggesting that: (1) the gD hairpin could be pre-formed and still allow HVEM binding; and (2) binding nectin-1 required a flexible $\mathrm{N}$-terminus of $\mathrm{gD}$. Thus, these data showed that there was no conformational change at the $\mathrm{N}$-terminus of $\mathrm{gD}$ that was common to binding of $\mathrm{gD} 285$ to these two receptors.

Once the structure of gD285 bound to nectin-1 was finally solved [64,65], it was confirmed that $\mathrm{gD}$ binds strictly to the V-domain of nectin-1, the same domain used for trans-interactions of nectin-1 with itself and other nectins [64,65,83] (Figure 3B). The crystal structure of the gD/nectin-1 complex confirmed and expanded the results of all of the previous mutagenesis experiments and also pointed to a critical role for Phe129 of nectin-1 in maintaining the interface with gD but protruding into a pocket within the $\mathrm{IgV}$-like core of $\mathrm{gD}$ (Figure 3B).

Since resolution of the gD285/HVEM and gD285/nectin-1 structures did not reveal a common conformational change in $\mathrm{gD}$, the connection between receptor binding and activation of fusion remained unanswered. However, gD285 is truncated well short of the transmembrane region (TMR) at 316. It was used for crystallization due to its high affinity $\left(10^{-8} \mathrm{M}\right)$ for both receptors which allowed stable complexes to form. In contrast, a longer form, gD306 has only micromolar affinity for HVEM or nectin-1 [66-68]. This contrast in affinities suggested that residues 285-306 impeded but did not prevent receptor binding. Interestingly, truncations as short as gD260 also had higher affinity for receptors than did gD306, again due to a higher rate of complex formation. Studies using the various truncated forms of $\mathrm{gD}$ to trigger entry of a gD-null virus led to the conclusion that residues 260-285 constitute a "profusion domain" [84]. A confounding observation was that consecutive 10 amino acid deletions along this region did not disrupt fusion [81]. However each 10 amino acid deletion left a large portion of this domain intact. Thus, it was possible that none of these deletions affected the overall position of this portion of gD. It was hypothesized then that HVEM or nectin-1 binding to gD306 required a conformational change to move the impediment caused by the $\mathrm{C}$-terminal residues. Since these residues are missing in gD285, no conformational change would be needed for receptors to bind.

To test this idea it was essential that a method be applied to stabilize the flexible C-terminus so as to reveal the residues between amino acid 260 and 306. For this, a mutant with a cysteine residue right after residue 306 was constructed $\left(\mathrm{gD} 306 \mathrm{t}_{307 \mathrm{Cys}}\right)$, forming a dimer locked at the C-terminus. The hope was that the added cysteine would result in an intermolecular disulfide bond between two monomers of $\mathrm{gD}$ thereby locking the two C-termini and the residues proximal to it (Figure 3C shows the protomer and Figure 2 shows the dimer) [63]. Indeed, this form of $\mathrm{gD}$ was crystallized and revealed that the positions of residues 269-306 snake closely across the $\mathrm{gD}$ core so that the $\mathrm{C}$-terminus is in fact close to the N-terminus of each monomer. In this structure the position of residues 269-306 prevents formation 
of the hairpin loop needed for HVEM binding to $\mathrm{gD}$ and obscures residues needed for nectin-1 binding to $\mathrm{gD}$. In fact, gDt306 $307 \mathrm{Cys}$ was unable to bind either receptor. According to this structure, these C-terminal residues must move away to allow both HVEM and nectin-1 to bind for a common conformational change to occur [85].

To confirm the validity of this structure, five additional disulfide bonded forms of monomeric $\mathrm{gD}$ were made choosing amino acids close enough in the structure of gDt306 307 Cys to restrain movement of various portions the $\mathrm{C}$-terminus [86]. Mutant 1 was the least restrained (locking amino acid 242 to 274) and mutant 6 , the original one described above was the most restrained, locking amino acid 37 to amino acid 302 in the context of a gD dimer [86]. Mutants 4, 5 and 6 were unable to bind receptors or trigger fusion and were therefore uninformative. Notably, mutants 1-3 retained the ability to bind receptors but were impaired in their ability to mediate fusion, with mutants 1 and 3 being partially crippled and mutant 2 (K190C-A277C) being completely unable to trigger either cell-cell fusion or to complement a gD-null virus. Thus, mutant 2 clearly separated the ability of gD to bind receptor from its ability to promote fusion. These results suggest that this second post-binding function of $\mathrm{gD}$ required only a portion of the C-terminus to be flexible and that residues in $\mathrm{WT} \mathrm{gD}$ that directly interact with $\mathrm{gH} / \mathrm{gL}$ and/or gB may also be obscured by the ectodomain $\mathrm{C}$-terminus, and are then revealed as the $\mathrm{C}$-terminus moves away from the core of $\mathrm{gD}$.

Interestingly, the structure of $\mathrm{gDt} 306_{307 \mathrm{Cys}}$ shows that the $\mathrm{C}$-terminal residues of the $\mathrm{gD}$ ectodomain are stabilized by the side chain of Trp294, which, along with Pro291 fit into a pocket formed by the $\mathrm{N}$-terminus and the central helix of $\mathrm{gD}$ (Figure 3A,B). This is the same pocket that is stabilized by Phe129 of nectin-1 at the $\mathrm{gD} /$ nectin-1 interface. In unliganded $\mathrm{gD}$ (Figure 3C), this structure of $\mathrm{gDt}_{307 \mathrm{Cys}}$ predicted that Trp294 of $\mathrm{gD}$ has to be displaced in order for nectin-1 to stably form a complex with gD. In fact, mutation of Phe129 of nectin-1 to either Leu or Ala has a negative effect on $\mathrm{gD}$ affinity for nectin-1 [87]. Mutation of Trp294 of gD increases binding of gD to nectin-1 but ablates the ability of a virus with this mutation to complement a gD null virus [63]. Interestingly, the fact that single amino acids such as Phe129 of nectin-1, Tryp294 of gD and Tyr23 of HVEM all act as "hot spot" residues that hold the interface between two proteins together has been documented for other proteins [88].

All of these mutants confirmed the structure of the C-terminal residues of the ectodomain of $\mathrm{gD}$. Importantly, a comparison between unliganded $\mathrm{gD}$, as seen in $\mathrm{gD} 06 \mathrm{t}_{307 \mathrm{Cys}}$ (Figure $3 \mathrm{C}$ ), with $\mathrm{gD}$ bound to either receptor shows that $\mathrm{C}$-terminal residues of the $\mathrm{gD}$ ectodomain must be displaced to allow either receptor to bind (Figure 3A,B). This common conformational change led to a model for receptor-activated triggering of the fusion machinery by $\mathrm{gD}[63,86]$. The model proposes that the $\mathrm{gD}$ ectodomain in the virus assumes a similar conformation as seen in the structure of $\mathrm{gDt}_{307 \mathrm{Cys}}$. In support of this a monoclonal antibody (AP7) originally isolated by Minson and colleagues [89] binds to an epitope that includes both the $\mathrm{N}$ - and $\mathrm{C}$-termini of the gD ectodomain [90]. This model also suggests that receptor binding sites are normally hidden in virion $\mathrm{gD}$ and are revealed only when the virus comes in contact with the appropriate receptor on a target cell.

Conformational changes have also been noted between the unbound and HLA Class II-bound forms of gp42 of EBV (Figure 3D,E), though they appear not to be quite as dramatic as the ones seen between $\mathrm{gD}$ and its receptors [4]. We suggest that this mechanism works to the advantage of both herpesviruses by preventing premature activation of the fusion machinery before the reaches its appropriate target cell within its human host. 


\section{Virus Neutralizing Antibodies to gD Target Its Two Separate Functions}

Previously, we and others identified a number of neutralizing monoclonal antibodies (MAbs) directed at HSV gD [91,92]. Many of them blocked binding of $\mathrm{gD}$ to one or both of its protein receptors [93,94]. In addition linker insertion mutants defined four functional regions (FR) of $\mathrm{gD}$ (Figure 4A and [90]). Forms of $\mathrm{gD}$ with mutations in each of these regions ablated or reduced virus infection, while having little or no effect on MAb binding. It is interesting that all of the epitopes for these neutralizing MAbs are found in FR1 and FR3 (Figure 4A), as originally defined by Chiang et al. [90]. We recently discovered an antibody, MC2, that neutralizes virus but does not block receptor binding and instead actually enhances it [95]. A portion of the epitope for this conformationdependent MAb may structurally overlap FR2 on a different face of gD than the face that binds other neutralizing MAbs and the receptors (Figure 4A) [95]. Thus, MC2 fits the model of a neutralizing antibody that blocks the fusion-activating function of $\mathrm{gD}$ while at the same time enhances receptor binding, possibly by moving the C-terminus away from the receptor-binding sites. Interestingly, a number of non-neutralizing MAbs whose epitopes are along the $\mathrm{C}$-terminus of gD (called FR4 in Figure 4A) also enhance receptor binding, suggesting that all of these MAbs induce the C-terminus to be in an "open" configuration. The unique properties of MC2 are likely conferred by the location of its epitope, such that antibody binding alters $\mathrm{gD}$ conformation to promote receptor binding. At the same time, antibody binding to the MC2 epitope interferes with conformational changes or interactions required for fusion. We hypothesized that residues either within or near the MC2 epitope might play a role in the second function of $\mathrm{gD}$. In this way MC2 is analogous to cysteine mutant 2 in defining the second $\mathrm{gD}$ function. Interestingly, both the neutralizing capacity and rate of neutralization of virus by MC2 is enhanced when combined with several of the non-neutralizing MAbs, all of which map to the same linear epitope (amino acids 262-272). We envision that stimulation of non-neutralizing antibodies by vaccines against HSV may play a role in protection by enhancing the neutralizing activity of specific antibodies against $\mathrm{gD}$ and perhaps other glycoproteins. A question that remains to be answered for MC2 is what step in the pathway to fusion does it block? For EBV, accessory proteins such as gp42 bind to $\mathrm{gH} / \mathrm{gL}$ once it binds its receptor. Perhaps receptor-activated $\mathrm{gD}$ also binds $\mathrm{gH} / \mathrm{gL}$, although no data have been reported that soluble, purified $\mathrm{gD}$ binds directly and tightly to purified $\mathrm{gH} / \mathrm{gL}$. Such an interaction has been reported to occur in bimolecular complementation studies [96] and in cell extracts [97]. Other evidence that such an interaction occurs will be described in a later section of this review.

\section{Structure-Function Analysis of $\mathrm{gH} / \mathrm{gL}$}

The heterodimeric complex $\mathrm{gH} / \mathrm{gL}$ is a component of the core fusion machinery of all herpesviruses. $\mathrm{gH} / \mathrm{gL}$ is also a major target of HSV neutralizing antibodies, as first shown by Peng et al. [98] and more recently for HCMV by Macagno et al. [99], highlighting its importance for virus infection. HSV-1 $\mathrm{gH}$ is an 838 amino acid glycoprotein with a large ectodomain and a single C-terminal transmembrane anchor [100]; gL is a 224 amino acid glycoprotein lacking a transmembrane region. Both proteins have signal peptides directing them into the secretory pathway. In HSV-infected cells and on mature virions, $\mathrm{gH}$ and $\mathrm{gL}$ are always found together in a stable 1:1 complex [98], as $\mathrm{gL}$ is 
required for correct folding and trafficking of gH. Specifically, expression of HSV gH in the absence of $\mathrm{gL}$ results in its intracellular retention, presumably in the endoplasmic reticulum. This abrogates generation of important epitopes [101-103] and prevents its incorporation into the viral envelope [104]. When HSV gL is expressed in the absence of $\mathrm{gH}$, some is secreted from mammalian cells $[105,106]$ although a substantial amount is retained inside the cells in its immature form (unpublished observations and [105]).

Until recently, little was known about the role of $\mathrm{gH} / \mathrm{gL}$ in fusion. The ability of transiently expressed Kaposi's sarcoma-associated herpesvirus (KSHV) gH/gL to mediate low level syncytia formation in the absence of any other viral proteins [107] suggested it may have some inherent fusogenic properties. Although similar observations have been made with $\mathrm{gH} / \mathrm{gL}$ from HCMV and varicella zoster virus (VZV) [35,108], not all $\mathrm{gH} / \mathrm{gL}$ proteins have such properties. In one study it was claimed that $\mathrm{HSV} \mathrm{gH} / \mathrm{gL}$ was responsible for hemifusion, whereas $\mathrm{gB}$ was involved with full fusion with a target membrane [109]. However, when the essential experiments of this study were recapitulated by a second group, they could not detect $\mathrm{gH} / \mathrm{gL}$ hemifusion [110].

Figure 4. Functional regions in herpes glycoproteins. All proteins are colored according to their structural regions, as defined previously for $\mathrm{HSV} \mathrm{gD}, \mathrm{HSV} \mathrm{gH} / \mathrm{gL}$, and $\mathrm{HSV} \mathrm{gB}$. (A) HSV gD. Two views of the monomeric, unbound form of $\mathrm{gD}$ are shown. The green (part of which is FR1; 27-43) represents the N-terminus which forms the HVEM-binding hairpin in the gD-HVEM complex. The Ig-like core (contains FR2, residues 125-161, and FR3, residues 225-246) is shown in yellow and the C-terminus (contains FR4; 277-310) in red. For reference, the MC2 (234-250; white) and MC10 (262-272; pink) epitopes are shown; (B) EBV gp42. Defined regions are as described in Kirschner et al. Binding sites for proteins $\mathrm{gH} / \mathrm{gL}$ (residues 36-81, within the green dotted circle) and HLA class II are indicated, as well as a distinct hydrophobic pocket essential for membrane fusion (black circles). The last two regions were defined by linker insertions; (C) HSV gH/gL. Two views of $\mathrm{gH} / \mathrm{gL}$ are shown. The $\mathrm{gH}$ structural domains are $\mathrm{H} 1$ (green), $\mathrm{H} 2$ (yellow), and $\mathrm{H} 3$ (orange). $\mathrm{gL}$ is shown in blue. HSV gH/gL FRs are defined by the epitopes of neutralizing MAbs: LP11 (FR1), 52S (FR2), and CHL17/32 (FR3). The integrin binding site (residues 176-178) is also indicated. Numerous mutations that affect cell-cell fusion map to domain $\mathrm{H} 3$; it is currently unknown if this is a functional domain separate from FR2 (which spans H2-H3); no known neutralizing MAbs map here; (D) EBV gH/gL. gL (blue) contains a hypothesized site of $\mathrm{gB}$ interaction. The integrin binding site (residues 188-190) is also indicated. Numerous mutations that affect fusion map to domain H3, as well as the epitope of the neutralizing MAb CL 59; (E) HSV gB. HSV gB FRs are defined by the epitopes of neutralizing MAbs: SS55/SS106/SS144 (FR1, blue and red, fusion domain), C226/H1838/H1781 (FR2, green, gH/gL interaction domain), SS10/SS67-69 (FR3, orange, receptor-binding domain). The epitope of MAb H1817 (FR4, dotted circle) maps to the unresolved N-terminus. The fusion loops are indicated at the bottom of the structure; (F) EBV gB. Chimeric EBV mutants have suggested that structural domains III (yellow), IV (orange) and $\mathrm{V}$ (red) are important for $\mathrm{gB}-\mathrm{gH} / \mathrm{gL}$ binding. The fusion loops are indicated at the bottom of the structure. 
A.

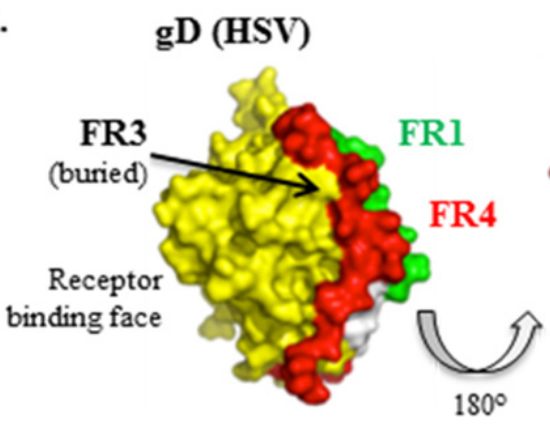

B. gp42 (EBV)
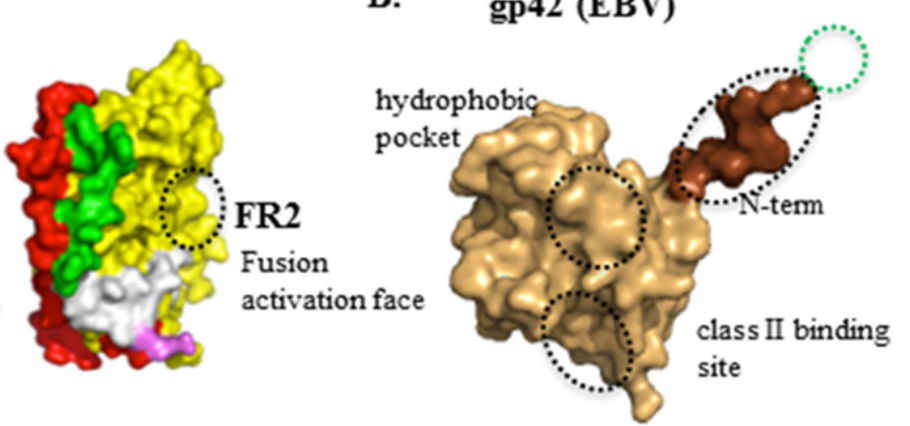

C.

$$
\text { gHgL (HSV) }
$$

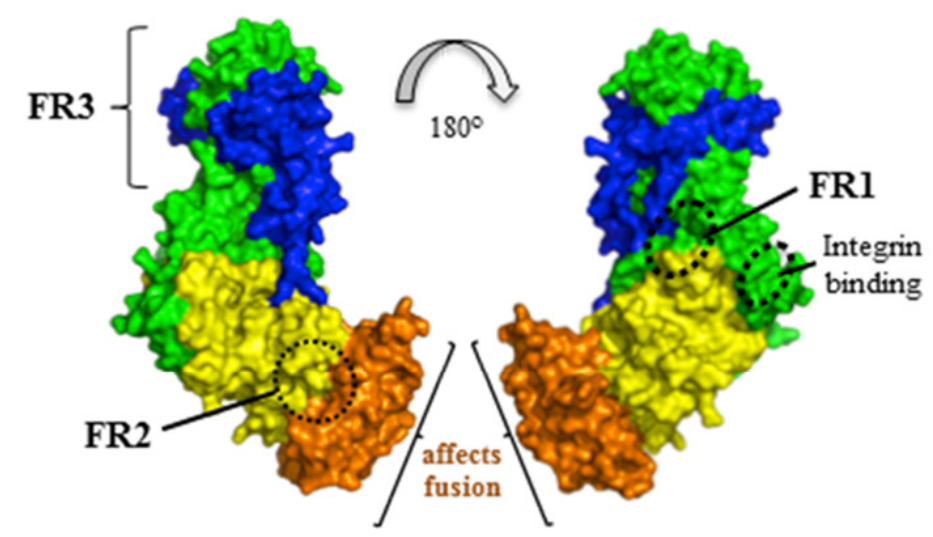

E.

gB (HSV)

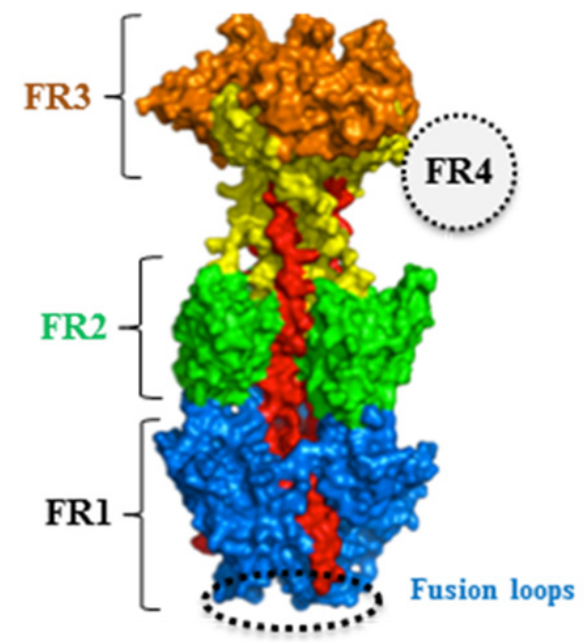

\section{D. $\mathrm{gHgL}$ (EBV)}

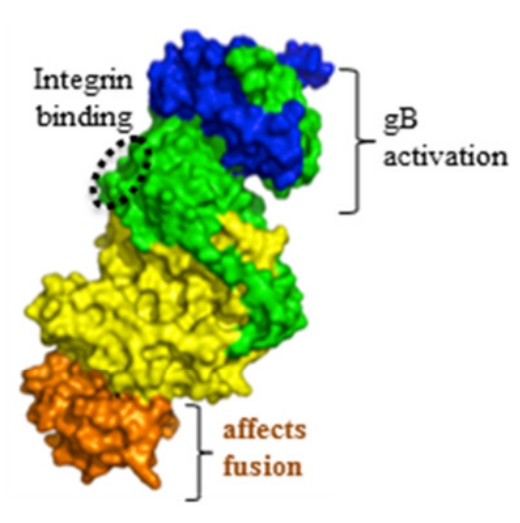

F.

gB (EBV)

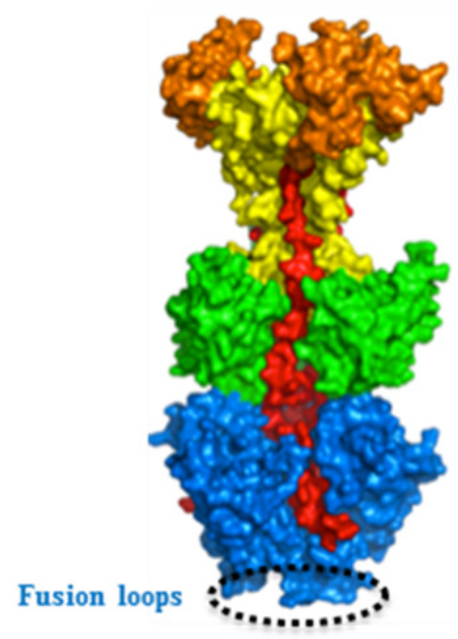

Several reports suggested that $\mathrm{gH}$ of a variety of herpesviruses functions as a viral fusion protein [35,107-109,111]. gH has been likened to class I viral fusion proteins based on studies carried out with peptides corresponding to predicted heptad repeats and fusion peptides [112-115], hydrophobic stretches within viral fusion proteins capable of binding to membranes. Several of the proposed fusion peptides of $\mathrm{gH}$ induced fusion in liposomes as synthetic peptides [114-116] but the full-length protein and the soluble, truncated forms of $\mathrm{gH} / \mathrm{gL}$ do not associate with lipid bilayers $[117,118]$. 
Recently, the crystal structure of nearly the entire gH ectodomain bound to full-length gL from HSV-2 was determined, revealing a boot-shaped heterodimer approximately $80 \AA \mathrm{X} 70 \AA$ (Figures 1 and 2) [119]. Shortly after this structure was reported, two additional reports revealed the structure of EBV gH/gL and a partial structure PRV gH [120,121] (Figure 1). In the case of HSV-2 gH/gL, the C-terminus of the $\mathrm{gH}$ ectodomain, which would normally lead into its transmembrane region, is located near the "sole" side of the "toe". The unusual shape of the $\mathrm{gH} / \mathrm{gL}$ structure is reminiscent of the 15-20 nm glycoprotein spikes, observed by cryo-electron tomography, which emerge from the HSV-1 envelope at an angle and often appear curved [122]. Therefore, each $\mathrm{gH} / \mathrm{gL}$ molecule on the virion surface probably appears to be standing on its "toe" and leaning to the side (Figure 2). Unexpectedly, the complex revealed by the crystal structure does not resemble any known viral fusion protein. In fact, unlike any viral fusion protein described to date, $\mathrm{gH} / \mathrm{gL}$ does not form a trimer [123-125]. In the case of EBV $\mathrm{gH} / \mathrm{gL}$, the complex is more cylindrical than boot-shaped (Figure 4D) [121] but the essential domain structure is quite similar.

HSV-2 gH has three structural domains: an N-terminal domain that binds gL ( $\mathrm{H} 1$, colored green in Figure 4C), a central helical domain (H2, colored yellow in Figure 4C), and a C-terminal $\beta$-sandwich domain (H3, colored orange in Figure 4C). For clarity, throughout this review we will refer to gH structural domains in EBV and PRV using these designations as well. The N-terminal domain of gH lacks a stable folded core and is stabilized by gL (colored blue in Figure 4C), which wraps around it, forming a clamp (Figure 4C). The second and third domains of gH of HSV, EBV and PRV are highly conserved in structure (Figures 1 and 4 ) and in fact these regions are well conserved in sequence across herpesviruses in general. Their hydrophobic nature has led investigators to suggest they play a supporting but key role in fusion (reviewed in [4]). However, in the crystal structure, peptides predicted to be fusion peptides based on their hydrophobicity are buried helices or $\beta$ hairpins in these C-terminal domains of $\mathrm{gH}$. In fact there are no gH peptides that are structurally similar to known fusion peptides [119]. Additionally, predicted heptad repeats (often found in fusion proteins) $[113,116,126]$ actually form helices, likely precluding a role in fusion. Thus, solution of the structure of $\mathrm{gH} / \mathrm{gL}$ contradicts previous assumptions that this heterodimer is a fusion protein that works in tandem with $\mathrm{gB}$. Instead, it provides an intriguing new puzzle as to how it is utilized to complement or regulate the fusion activity of $\mathrm{gB}$.

Although $\mathrm{gH}$ proteins are conserved among different herpesviruses, the sequence conservation is uneven across the protein $[119,127]$. Domain H1 is the most divergent, while domains H2 and H3 are more conserved, with each of the latter two domains having the same fold in HSV-2, EBV, and PRV $\mathrm{gH}$ (Figure 2 and Figure 4D). Yet, in EBV, the overall $\mathrm{gH} / \mathrm{gL}$ structure is more of an elongated cylinder than a boot (Figure 4D) [121]. The strong conservation of domain H3 suggests that it is functionally important. In support, several non-functional mutations map to this domain in both HSV-1 [128] and EBV [129] and a potent neutralizing MAb (CL 59) for EBV is directed at this domain [129]. Since this is the most conserved domain of $\mathrm{gH}$, one can speculate that $\mathrm{H} 3$ serves a similar function in other herpesviruses. It is noteworthy that the $\mathrm{N}$-terminal region of $\mathrm{gH}$ that binds $\mathrm{gL}$ as well as gL itself is strikingly different in the EBV and HSV proteins. Indeed, gL proteins are non-conserved in sequence across the herpesviruses. Thus, it has been argued that gL has evolved in tandem with changes to the structure of H1 [4,119]. An in silico model of the gH/gL structure of VZV has been calculated by Arvin and colleagues [130] and bears similarities to its HSV orthologs, 
suggesting that the $\mathrm{gH} / \mathrm{gL}$ structures of herpes viruses in general will bear similarities to those that have already been solved by X-ray crystallography.

Neutralizing MAbs directed at HSV gH, gL, or both have been useful in defining functional regions (FR) of the heterodimer (Figure 4C). Presumably, each of these regions plays a different role in $\mathrm{gH} / \mathrm{gL}$ function, although additional data will be needed to support this idea. For HSV gH/gL, we define FR1 by the mapping studies done for the LP11 epitope, since it is the most potent neutralizing antibody yet isolated against this protein. Its residues were defined by monoclonal antibody-resistant mutants and map to different places in the N-terminal half of $\mathrm{gH}[119,128,131]$. In addition to its effect on virus replication, MAb LP11 blocks cell-cell fusion and prohibits the interaction of $\mathrm{gB}$ with $\mathrm{gH} / \mathrm{gL}$, as seen by bimolecular complementation [119]. We therefore think that FR1 is the site of binding of $\mathrm{gH} / \mathrm{gL}$ to $\mathrm{gB}$, a necessary interaction for fusion [119]. Interestingly, the same face of $\mathrm{gH} / \mathrm{gL}$ is implicated for $\mathrm{gB}$ binding in EBV, albeit slightly further upstream on the heterodimer, within gL [132,133] (Figure 4D). FR2 of HSV $\mathrm{gH} / \mathrm{gL}$ is defined by the position of the $52 \mathrm{~S}$ epitope [131] and is on the opposite face of $\mathrm{gH} / \mathrm{gL}$ when compared with the position of the LP11 epitope. In addition to being a neutralizing antibody, 52S inhibits cell-cell fusion. Importantly it does not block the association of $\mathrm{gH} / \mathrm{gL}$ with $\mathrm{gB}$ as seen by bimolecular complementation [119]. We believe this interaction is necessary for and precedes cell-cell fusion [134]. These results suggest that FR2 carries out a function that occurs after that carried out by FR1. Lastly, FR3 includes the epitopes of MAbs CHL17 and CHL32, located at the gH N-terminus (residues 19-38) [103,135]. These two MAbs not only neutralize virus and block cell-cell fusion, but also limit cell-cell spread. Three other $\mathrm{gH} / \mathrm{gL}$ MAbs also inhibit spread: CHL2 (whose epitope is in domain H1, near gH residue 116), and CHL39 and CHL18 (whose epitopes are within the gL C-terminus) [103]. Thus, at this time we define FR3 to include both H1 and the gL C-terminus (Figure 4C). FR3 is unique from FR1 and FR2 in that it includes MAbs that affect cell-cell spread. Unfortunately, there are no comparable MAbs for EBV and this portion of the structure is missing from that which was solved for PRV gH/gL [120].

Although its role as part of the core fusion machinery is still open to debate, the requirement of $\mathrm{gH} / \mathrm{gL}$ for fusion is undisputed. Important clues about how $\mathrm{gH} / \mathrm{gL}$ functions may lie in its close association with accessory proteins, including UL128-131 of CMV [40] and gp42 (reviewed in [4]). In $\mathrm{HSV}$, bimolecular complementation was used to show an association between $\mathrm{gD}$ and gH/gL [96,136]. $\mathrm{HSV} \mathrm{gH} / \mathrm{gL}$ also contains an integrin binding motif (RGD) (Figure 4C,D). However mutation of RGD to RGE had no effect on the ability of the recombinant virus to replicate [128]. There is conflicting evidence as to whether or not integrins are necessary for HSV gH/gL to bind to cells $[137,138]$ but a similar site has been found in EBV $\mathrm{gH} / \mathrm{gL}[15,121]$; their positions are shown in Figure 4C for HSV and Figure 4D for EBV. Although the role of integrins and $\mathrm{gH} / \mathrm{gL}$ function has not yet been fully resolved, the fact that the integrin motif can be mutated without affecting virus infection suggests that $\mathrm{gH} / \mathrm{gL}$ binding to cellular integrins does not trigger fusion.

Based on the unique structure of $\mathrm{gH} / \mathrm{gL}$ resolved in whole or in part for several herpesviruses, we propose that it is not a fusion protein but instead its function is to activate the inherent fusogenic capability of $\mathrm{gB}$. As such, $\mathrm{gH} / \mathrm{gL}$ may provide a signal to $\mathrm{gB}$ that is functionally analogous to the triggering of fusion proteins of RNA viruses by low $\mathrm{pH}$ [123]. Indeed, conversion of the $\mathrm{gB}$ analog VSV G from a pre- to a post-fusion state depends on the acid environment of the endosome that VSV 
is taken into [139]. Other fusion triggering mechanisms such as protease cleavage, e.g., Nipah virus $[140,141]$, may also be functionally analogous to the action of $\mathrm{gH} / \mathrm{gL}$.

\section{The Structure of gB and Its Role in HSV Entry}

Although early observations of $\mathrm{gB}$ mutants with hyperfusogenic phenotypes suggested the involvement of $\mathrm{gB}$ in fusion [142], the crystal structure provides the most convincing evidence that $\mathrm{gB}$ functions as a viral fusion protein [143]. Indeed, its domain structure is quite similar to that of $G$, the fusion glycoprotein of vesicular stomatitis virus (VSV) [144] and the fusion protein of baculovirus gp64 [145]. As these proteins show no sequence similarities, the similarity in structure is remarkable given that these proteins belong to unrelated viruses. Because these proteins bear structural features of both Class I and Class II fusion proteins, they now constitute a new class of fusion proteins, Class III. In each case, the Class III proteins are trimeric with three long central $\alpha$-helices (like Class I fusion proteins) and what appear to be two internal fusion loops per protomer, reminiscent of the single fusion loop of Class II fusion proteins [123].

In the structure, the $\mathrm{gB}$ ectodomain trimer forms a spike-like molecule with the approximate dimensions of $85 \AA ̊ x 80 \AA ̊ x 160 \AA$. Similarly shaped spikes of gB have been observed on HSV-1 virions using electron microscopy [146]. Each protomer consists of five distinct structural domains in which domain I is located at the base of the gB spike, proximal to the membrane. Moreover, domain I contains two proposed fusion loops, as revealed by a series of fusion-loop mutants of both HSV and EBV [147-149]. The two loops constitute a fusion domain on each protomer such that hydrophobic residues are flanked by charged residues [149], and mutational analysis provides good evidence that the proposed fusion loops of $\mathrm{gB}$ are in fact responsible for membrane insertion. Among the mutants constructed, three with a null phenotypes for cell-cell fusion showed major defects in egress [150] as well as viral entry [149], indicating that fusion events associated with both entry and egress of HSV require and use $\mathrm{gB}$ in the same fashion.

\section{Understanding the Conversion of Pre-Fusion Form of gB to a Post-Fusion State is Hampered by the Lack of a Pre-Fusion Structure}

Unlike $\mathrm{gB}$, there are now structural data for both pre-fusion and post-fusion forms of VSV G. The structure of the $\mathrm{gB}$ ectodomain has obvious similarities with the extended post-fusion but not the folded-in pre-fusion structure of VSV G [144,151]. It is therefore likely that the available structure of $\mathrm{gB}$ represents the post-fusion conformation, but this is yet to be confirmed. Conformational changes to $\mathrm{gB}$ in response to low $\mathrm{pH}$, as in endosomes, have been reported [118,152], although crystal structures of truncated $\mathrm{gB}(\mathrm{gB} 730)$ at low $\mathrm{pH}$ suggests that many of these reported changes are relatively small [153] and do not resemble the profound changes in structure seen for VSV G [151]. Of note however, in the structure of $\mathrm{gB} 730$, the fusion loops are positioned quite close to where the transmembrane region (TMR) would begin. There is also a membrane proximal region from amino acid 730-773 (just upstream of the TMR) for which structure has not been resolved. This region is essential and it is not clear where these residues are in a pre- or post-fusion form of $\mathrm{gB}$. A model for such a form was suggested for EBV gB, based on that of VSV G [154]. This model suggests that conversion of $\mathrm{gB}$ from pre- to post-fusion involves the same "foldback" mechanism seen for most if 
not all fusion proteins of RNA viruses [123]. However, since $\mathrm{gB}$ cannot function as a fusion protein in the absence of $\mathrm{gH} / \mathrm{gL}$ it may be synthesized or processed into a novel form. Two possibilities that have been explored are the role of $\mathrm{pH}$ and proteases in $\mathrm{gB}$ activation. Although some gB proteins, e.g., $\mathrm{gB}$ of EBV undergo a protease cleavage that may be involved in its activation [155], there is no evidence that this occurs with HSV gB. Furthermore, mutation of the protease cleavage site in bovine herpes virus type 1 (BHV-1) and PRV gB has no effect on virus infectivity [156], although more subtle effects on cell-cell fusion may occur. Thus there may be some variability in how $\mathrm{gB}$ reaches a fusion active state and $\mathrm{pH}$ may play a role in HSV fusion when it occurs in endosomes [152]. Understanding the structural basis for the transition of $\mathrm{gB}$ from a pre- to post-fusion state and how it is triggered remain one of the challenges for the future.

\section{Functional Studies of gB with Mutants and Monoclonal Antibodies}

Until the structure of $\mathrm{gB}$ was solved, studies of constructed mutations was a frustrating exercise, which is unsurprising given the complex structure of the trimer [157-160]. Once the structure was solved, the previously constructed mutants could be mapped onto the gB structure [160-162] and new mutagenesis studies could be carried out in a more rational and targeted fashion, e.g., studies of the fusion loops $[148,149,163,164]$.

Because $\mathrm{gB}$ is the target of many neutralizing antibodies, investigators have used MAbs to map important regions of $\mathrm{gB}[134,149,160,165-168]$. Once the structure of HSV-1 gB was solved, epitope mapping efforts were directed at defining functional regions (FR) on the structure itself. Dividing $\mathrm{gB}$ into FRs based on where epitopes for neutralizing MAbs map has pinpointed places that must be involved in $\mathrm{gB}$ function. Based on this mapping, 4 FRs have been proposed for HSV (Figure 4E and [168]). FR1 contains the fusion loops [148], FR2 is located on the outward-facing middle region of $\mathrm{gB}$, while FR3 maps to the outer ridge of the gB "crown" [143]. Finally, FR4 is composed of a region at the N-terminus of $\mathrm{gB}$ which was not solved in the crystal structure. In addition to being the site of binding of several neutralizing MAbs, it contains the heparan sulfate binding region [159] and might also bind to other cell surface molecules [149,168-171]. Both FR1 and FR2 contain Pleckstrin-homology domains (PH) suggestive of interactions with both lipids and proteins [143]. The location of one of these domains in FR1 is consistent with the fact that $\mathrm{gB}$ inserts into liposomes via its fusion loops. Location of the other PH domain in FR2 suggests that this region may be involved in the interaction of $\mathrm{gB}$ with $\mathrm{gH} / \mathrm{gL}$. Evidence for this will be summarized in section 12 below. It should be noted that EBV may have similar functional regions but no mapping with MAbs has been reported thus far.

\section{Interactions Between $\mathrm{gB}$ and $\mathrm{gH} / \mathrm{gL}$}

Since $\mathrm{gB}$ and $\mathrm{gH} / \mathrm{gL}$ are both needed for fusion, a major puzzle in the field has been to decipher whether they work sequentially or as a complex that could potentially also include gD and receptors. Earlier, it was suggested that entry occurs in a stepwise fashion beginning with $\mathrm{gD}$, followed at some point by $\mathrm{gH} / \mathrm{gL}$ [172]. However, complexes of HSV gB-gH/gL have been detected in lysates of infected and transfected cells [97,173]. Complexes between CMV gH/gL and $\mathrm{gB}$ can also be immunoprecipitated from lysates of cells transduced with adenovirus vectors carrying genes for $\mathrm{gB}$ and $\mathrm{gH} / \mathrm{gL}$ [44], but even so, it does not mean that this complex represents a functional unit for fusion 
in intact cells. A more biologically relevant approach is one that would occur in intact cells, especially under conditions leading to fusion.

Recently, bimolecular fluorescence complementation (BiMC or BiFC) was developed to detect protein interactions in intact transfected cells [174-177] using confocal microscopy. In the first reports applying this technique to HSV glycoproteins, we and others found that $\mathrm{gB}$ and $\mathrm{gH} / \mathrm{gL}$ can interact with each other, but only when both $\mathrm{gD}$ and a $\mathrm{gD}$ receptor are also present $[96,136]$. However, in a follow-up study, it was reported that $\mathrm{gB}$ interacts with $\mathrm{gH} / \mathrm{gL}$ in the absence of fusion or $\mathrm{gD}$ [173]. This would agree with the in vitro work, but would also mean that the interaction was not driven by $\mathrm{gD}$ binding to receptors. However, the latter study was flawed by overexpressing a mutant form of $\mathrm{gB}$ trafficked in an abnormal manner. As pointed out by the developers of the assay $[175,176,178,179]$ it is essential that the proteins not be over-expressed and that they be expressed in the proper cell compartment to avoid artifacts.

To gain more evidence that the interaction between $\mathrm{gB}$ and $\mathrm{gH} / \mathrm{gL}$ only occurs in response to binding of $\mathrm{gD}$ to one of its receptors and is an essential step prior to fusion, MAbs to $\mathrm{gB}$ and $\mathrm{gH} / \mathrm{gL}$ were used to try to block the interaction between $\mathrm{gB}$ and $\mathrm{gH} / \mathrm{gL}[119,134]$. The rationale was that if the interaction is essential for fusion/entry, it should be blocked only by antibodies that neutralize HSV infectivity or by antibodies that block fusion. Likewise, non-neutralizing MAbs should have no effect. Moreover, MAbs that blocked BiMC but not fusion would separate sites required for $\mathrm{gB}-\mathrm{gH} / \mathrm{gL}$ interactions early in fusion from those required at later stages. Indeed, most of the neutralizing MAbs were able to block fusion and a subset of antibodies to $\mathrm{gB}$, as well as one to $\mathrm{gH} / \mathrm{gL}$, only blocked the interaction with $\mathrm{gH} / \mathrm{gL}$, but not fusion. Among the former, the epitopes for many of them mapped to a region that contains the fusion loops of $\mathrm{gB}[148,149]$.

Among the latter group of MAbs were several that blocked fusion but not interaction with $\mathrm{gH} / \mathrm{gL}$, and mapped to a region not resolved in the crystal structure near the N-terminus of $\mathrm{gB}$, suggesting that this region has an as yet unknown function, perhaps involving interaction with a cell protein $[168,169]$. Fewer neutralizing MAbs were available for $\mathrm{gH} / \mathrm{gL}$ but one in particular, LP11 [131,180], was able to block both fusion and the interaction with gB [119]. Additional MAbs with known epitopes together with mutants will eventually pinpoint the site of the interaction between $\mathrm{gB}$ and $\mathrm{gH} / \mathrm{gL}$. Of course, the best way to detail the interaction will be to co-crystallize $\mathrm{gB}$ with $\mathrm{gH} / \mathrm{gL}$, a challenge for the future. Together these studies suggest a stepwise progression of events from binding of $\mathrm{gD}$ to receptor to the end result of fusion. One theory regarding how $\mathrm{gH} / \mathrm{gL}$ functions in fusion was suggested for PRV [120]. This theory focuses on an extended "flap" of gH that masks a conserved hydrophobic patch in the most C-terminal domain of this protein. It suggested that unmasking of this flap exposes a hydrophobic surface that then participates in fusion. Since this region of $\mathrm{gH}$ is the most highly conserved among herpesviruses, this mechanism might be broadly used. Indeed, there are several publications supporting the idea that this region of the ectodomain, as well as the transmembrane region may impact fusion [181-183].

\section{Fusion in trans Reveals Additional Information about gH/gL Function}

An intriguing clue about $\mathrm{gH} / \mathrm{gL}$ function in general came from studies carried out by Vanarsdall et al. [44] for fusion induced by CMV glycoproteins. They found that cells could be 
transduced separately with Adenovirus vectors for $\mathrm{gH} / \mathrm{gL}$ and $\mathrm{gB}$ and that fusion occurred when the two cell populations were mixed. Their result was the first description of a multi-component viral fusion machine that could be split between cells (fusion in trans). This startling result, which was observed prior to solution of the structure of $\mathrm{gH} / \mathrm{gL}$, was difficult to explain if $\mathrm{gH} / \mathrm{gL}$ had to be in the same membrane as $\mathrm{gB}$ in order to act as a "co-fusogen" or even as an independent fusogen that added to a poorly fusogenic $\mathrm{gB}$. Although the observation about CMV glycoproteins was met with initial skepticism (including ours), it made much more sense once the structure of $\mathrm{gH} / \mathrm{gL}$ was solved. Since $\mathrm{gH} / \mathrm{gL}$ did not look like a fusion protein, we first assumed that it wasn't. In that case, we hypothesized that its ability to participate in fusion would not require it to be in the same membrane as $\mathrm{gB}$. In support, we found that receptor-positive B78H1 (C10) mouse melanoma cells expressing gH/gL fused with receptor-negative $\mathrm{B} 78 \mathrm{H} 1$ cells expressing $\mathrm{gB}$ and $\mathrm{gD}$ (fusion in trans) [184]. Second, fusion also occurred when $\mathrm{gH} / \mathrm{gL}$-expressing $\mathrm{C} 10$ cells that had been pre-exposed to soluble gD306 were subsequently co-cultured with gB-expressing B78H1 (receptor negative) cells. In contrast, prior exposure of gB-expressing $\mathrm{C} 10$ cells to soluble $\mathrm{gD}$ did not promote subsequent fusion with $\mathrm{gH} / \mathrm{gL}$-expressing B78H1 cells. These data support the original observation made by Vanarsdall et al. for CMV [44].

Of greater importance, current data also suggest that HSV fusion first involves activation of $\mathrm{gH} / \mathrm{gL}$ by receptor-bound $\mathrm{gD}$ and that $\mathrm{gH} / \mathrm{gL}$ does not even have to be membrane bound to function. Specifically, we found that soluble $\mathrm{gH} / \mathrm{gL}$, where $\mathrm{gH}$ is truncated prior to the transmembrane region, triggers a low level of fusion of $\mathrm{C} 10$ cells expressing $\mathrm{gD}$ and $\mathrm{gB}$; a much higher level is achieved when $\mathrm{gB}$-expressing $\mathrm{C} 10$ cells are exposed to a combination of soluble $\mathrm{gH} / \mathrm{gL}$ and soluble $\mathrm{gD}$. Of course the level of fusion induced by the soluble proteins or even when $\mathrm{gB}$ and $\mathrm{gH} / \mathrm{gL}$ are in trans is much lower than what occurs when all 4 glycoproteins are in cis. This is to be expected as this is the optimal configuration, i.e., that found in the virus. Fusion in trans and with soluble $\mathrm{gH} / \mathrm{gL}$ does not preclude the possibility that the C-terminal domain of $\mathrm{gH}$ plays a role in the fusion process itself. The low efficiency of fusion in trans and other more technical issues might account for two previous reports that fusion by HSV glycoproteins was induced only when $\mathrm{gD}, \mathrm{gB}$, and $\mathrm{gH} / \mathrm{gL}$ were in cis $[185,186]$. However, these experiments show that the only protein that needs to be membrane bound to function is $\mathrm{gB}$ and we believe this is solid evidence that it is the sole fusogen of HSV and likely to be the key fusogen of all herpesviruses..

\section{Model for Herpesvirus Fusion and How It Relates to Fusion by Other Viruses}

We suggest that fusion occurs in an exquisitely regulated stepwise process (Figure 5 shows this for HSV) that consists of the following steps: (1) For HSV, gD binds to a receptor, either HVEM or nectin-1, and undergoes conformational changes in that process; for EBV, gp42 binds to HLA receptor molecule on B cells and may undergo somewhat more modest changes; (2) The activated form of these receptor-binding proteins now allows them to bind to convert $\mathrm{gH} / \mathrm{gL}$ into a form that interacts with $\mathrm{gB}$; this brings the two membranes together followed by insertion of fusion loops into the cell membrane (steps 3 and 4). This leads to step (5) that consists of fusion of the two membranes and delivery of the capsid into the cell (entry). We suggest that the final two steps are likely be common to other herpesviruses since they all use both $\mathrm{gB}$ and $\mathrm{gH} / \mathrm{gL}$ for fusion. Although our model predicts that conversion of $\mathrm{gB}$ from a resting state to an active fusogenic state is doubly regulated in HSV and 
possibly EBV, we do not yet know if this mechanism for $\mathrm{gB}$ activation applies across the herpesviruses. However, it is especially clear that $\mathrm{gB}$ is the only fusion protein of HSV.

Figure 5. Cartoon representation of the sequential events leading to HSV entry. The entry process begins with the binding of $\mathrm{gD}$ to specific receptors (nectin-1 is shown), to gain entry into target cells (step 1). Receptor binding triggers displacement of the C-terminus of $\mathrm{gD}$ to expose a previously hidden region of $\mathrm{gD}$, which we propose interacts with $\mathrm{gH} / \mathrm{gL}$ (step 2). This interaction results in a conformational change in $\mathrm{gH} / \mathrm{gL}$ that enables it to up-regulate $\mathrm{gB}$ into a fusogenic state. This three-step process may involve the interaction of $\mathrm{gB}$ with a cell surface protein, the insertion of $\mathrm{gB}$ fusion loops into the opposing lipid membrane (step 3) and an interaction between the ectodomains of $\mathrm{gB}$ and $\mathrm{gH} / \mathrm{gL}$ (step 4). This converts $\mathrm{gB}$ from a pre- to a post-fusion state, resulting in fusion of the viral envelope with cell membranes and delivery of the nucleocapsid into the target cell (step 5). All essential proteins shown were drawn based on published structures with the corresponding domains. Where pre-activation structures were not available, the proteins are shown in gray.
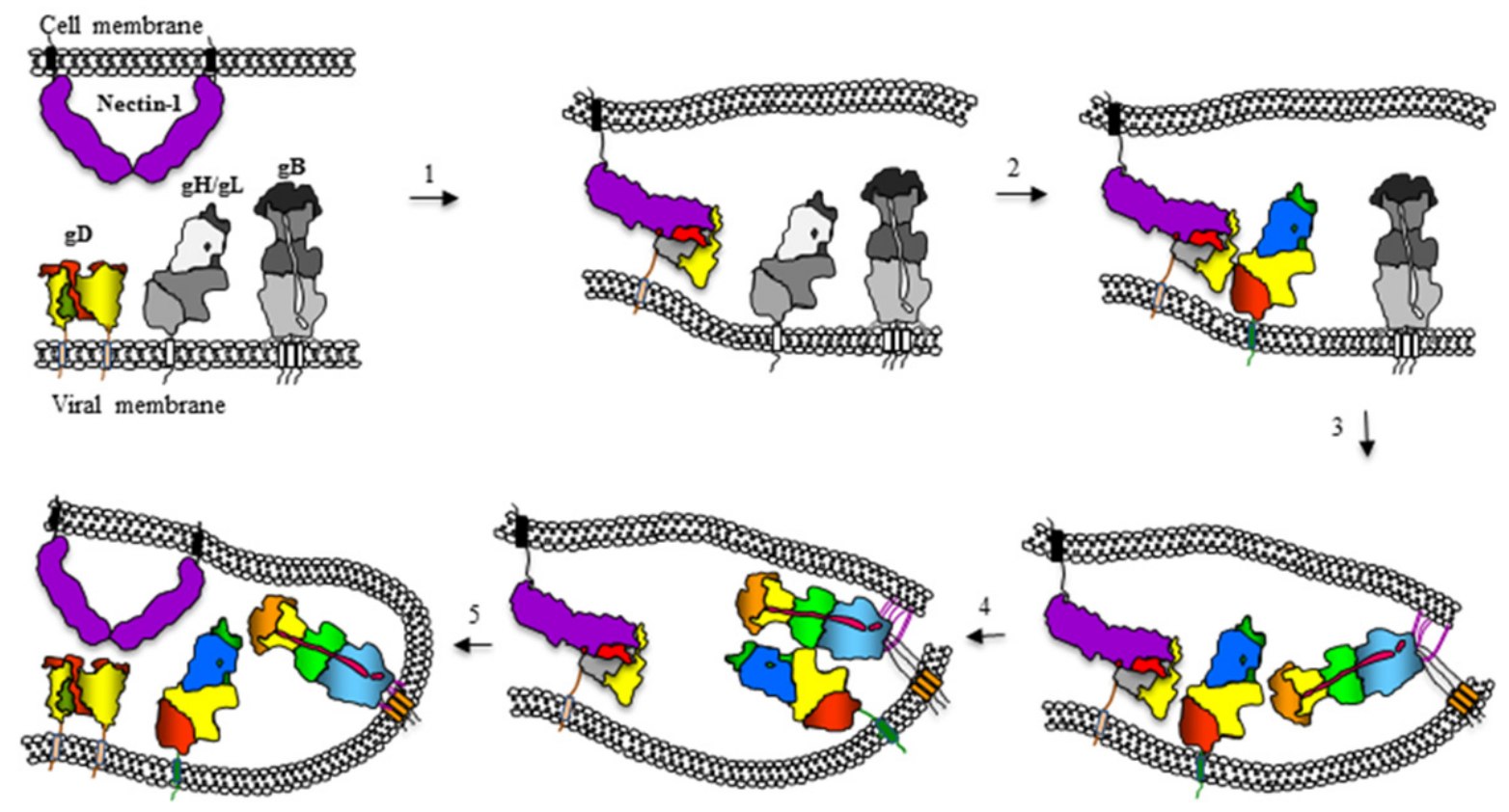

Our data suggests that the interaction between $\mathrm{gD}$ and $\mathrm{gH} / \mathrm{gL}$ in cells is necessarily transient or weak. Stabilization of a $\mathrm{gD}-\mathrm{gH} / \mathrm{gL}$ complex occurred even when $\mathrm{gB}$ was absent, excluding the possibility of fusion [96]. However, when gB was present, no fusion occurred, suggesting that this complex has to dissociate for the fusion process to proceed. When we stabilized the complex of these proteins at the C-termini of the two proteins with EYFP tags, no fusion occurred when $\mathrm{gB}$ and the receptor were also present $[96,136]$. However, there have been studies showing that $\mathrm{gD}$ and $\mathrm{gH} / \mathrm{gL}$ can be co-precipitated from cell extracts, though it is uncertain whether this complex represents a functional one [97]. In contrast, the interaction between gp42 and $\mathrm{gH} / \mathrm{gL}$ of EBV is necessarily quite strong and has a positive effect on fusion $[16,55,60,187,188]$. Thus, there is likely to be variability in how each of these proteins activates $\mathrm{gH} / \mathrm{gL}$; the low $\mathrm{pH}$ of the endosome may play an important role in accounting for these differences. It is important to note that the system we used to study $\mathrm{gB}$ and $\mathrm{gH} / \mathrm{gL}$ 
in cis vs. trans in cell-cell fusion more closely resembles cell-cell spread than virus entry. A future challenge will be to determine how the outlines of this fusion "pathway" apply to herpesvirus entry.

Finally, we suggest that that fusion induced by herpesvirus glycoproteins is similar in at least some respects to fusion induced by the single glycoproteins of RNA viruses, such as influenza HA, flavivirus E and even VSV G [123,189]. But the closest example to herpesvirus fusion/entry is that of the paramyxoviruses which employ one viral glycoprotein to bind receptor $(\mathrm{G})$ and a second virally encoded glycoprotein (F) to carry out fusion [190-192]. In this family of viruses, all have similar mechanisms to activate $\mathrm{F}$ including protease cleavage, but receptor binding varies widely [191]. Although common mechanisms of fusion protein proteolytic activation and the mechanism of membrane fusion promotion have been shown in recent years, considerable diversity exists in the family relating to receptor binding and the potential mechanisms of fusion triggering. One particularly interesting example is the Henipavirus genus of viruses [192,193]. Unlike many members of the Paramyxovirus family that use glycan receptors, members of the Henipavirus genus use protein-based receptors (ephrinB2 and ephrinB3) for virus entry [194]. Receptor binding by G triggers a cascade of conformational changes and protease cleavages that ultimately result in membrane fusion. We suggest that fusion by this group of viruses also occurs in a stepwise manner that resembles our model for how HSV fusion is accomplished (Figure 5). However, in both cases, dissecting the mechanism by which receptor binding activates the receptor binding protein which in turn activates the fusion machinery remains a challenge for future investigation. Still, structural biology coupled with biochemistry and immunology, have clarified many aspects of herpesvirus fusion and have proven that fusion is due to a single glycoprotein whose activity is exquisitely regulated by other viral glycoproteins and their receptors.

\section{Acknowledgments}

Support for this review was provided by grants NIH R01-AI056045, Ai076231 to RJE, AI-18289 to GHC and T32-AI007324 to JG. We thank Leslie King of the School of Veterinary Medicine for her excellent help in editing this manuscript and providing very useful commentary. We also thank all the members of the laboratories of RJE and GHC for wonderful technical support and stimulating ideas and Katya Heldwein and Andrea Carfi for their contributions to our understanding of HSV entry.

\section{Conflict of Interest}

The authors declare no conflict of interest.

\section{References}

1. Campadelli-Fiume, G.; Menotti, L. Entry of Alphaherpesviruses into the Cell. In Source Human Herpesviruses: Biology, Therapy, and Immunoprophylaxis; Arvin, A., Campadelli-Fiume, G., Mocarski, E., Moore, P.S., Roizman, B., Whitley, R., Yamanishi, K., Eds.; Cambridge University Press: Cambridge, UK, 2007; Chapter 7.

2. Campadelli-Fiume, G.; Menotti, L.; Avitabile, E.; Gianni, T. Viral and cellular contributions to herpes simplex virus entry into the cell. Curr. Opin. Virol. 2012, 2, 28-36. 
3. Navaratnarajah, C.K.; Miest, T.S.; Carfi, A.; Cattaneo, R. Targeted entry of enveloped viruses: Measles and herpes simplex virus I. Curr. Opin. Virol. 2012, 2, 43-49.

4. Connolly, S.A.; Jackson, J.O.; Jardetzky, T.S.; Longnecker, R. Fusing structure and function: A structural view of the herpesvirus entry machinery. Nat. Rev. Microbiol. 2011, 9, 369-381.

5. Hutt-Fletcher, L.M.; Chesnokova, L.S. Integrins as triggers of Epstein-Barr virus fusion and epithelial cell infection. Virulence 2010, 1, 395-398.

6. Akhtar, J.; Shukla, D. Viral entry mechanisms: Cellular and viral mediators of herpes simplex virus entry. FEBS J. 2009, 276, 7228-7236.

7. Browne, H.M. The role of glycoprotein $\mathrm{H}$ in herpesvirus membrane fusion. Protein Pept. Lett. 2009, 16, 760-765.

8. Sinzger, C.; Digel, M.; Jahn, G. Cytomegalovirus cell tropism. Curr. Top. Microbiol. Immunol. 2008, 325, 63-83.

9. Mori, Y. Recent topics related to human herpesvirus 6 cell tropism. Cell. Microbiol. 2009, 11, 1001-1006.

10. Sinzger, C. Entry route of HCMV into endothelial cells. J. Clin. Virol. 2008, 41, 174-179.

11. Ryckman, B.J.; Jarvis, M.A.; Drummond, D.D.; Nelson, J.A.; Johnson, D.C. Human cytomegalovirus entry into epithelial and endothelial cells depends on genes UL128 to UL150 and occurs by endocytosis and low-pH fusion. J. Virol. 2006, 80, 710-722.

12. Spear, P.G.; Eisenberg, R.J.; Cohen, G.H. Three classes of cell surface receptors for alphaherpesvirus entry. Virology 2000, 275, 1-8.

13. Li, Q.; Spriggs, M.K.; Kovats, S.; Turk, S.M.; Comeau, M.R.; Nepom, B.; Hutt-Fletcher, L.M. Epstein-Barr virus uses HLA class II as a cofactor for infection of B lymphocytes. J. Virol. 1997, $71,4657-4662$.

14. Wang, X.; Hutt-Fletcher, L.M. Epstein-Barr virus lacking glycoprotein gp42 can bind to B cells but is not able to infect. J. Virol. 1998, 72, 158-163.

15. Chesnokova, L.S.; Nishimura, S.L.; Hutt-Fletcher, L.M. Fusion of epithelial cells by Epstein-Barr virus proteins is triggered by binding of viral glycoproteins gHgL to integrins alphavbeta6 or alphavbeta8. Proc. Natl. Acad. Sci. USA 2009, 106, 20464-20469.

16. Chen, J.; Rowe, C.L.; Jardetzky, T.S.; Longnecker, R. The KGD motif of Epstein-Barr virus $\mathrm{gH} / \mathrm{gL}$ is bifunctional, orchestrating infection of B cells and epithelial cells. MBio 2012, 3, doi:10.1128/mBio.00290-11.

17. Leoni, V.; Gianni, T.; Salvioli, S.; Campadelli-Fiume, G. Herpes simplex virus gH/gL and gB bind TLR2 and soluble $\mathrm{gH} / \mathrm{gL}$ is sufficient to activate NF-kappaB. J. Virol. 2012, doi:10.1128/JVI.00295-12.

18. Juckem, L.K.; Boehme, K.W.; Feire, A.L.; Compton, T. Differential initiation of innate immune responses induced by human cytomegalovirus entry into fibroblast cells. J. Immunol. 2008, 180, 4965-4977.

19. Boehme, K.W.; Singh, J.; Perry, S.T.; Compton, T. Human cytomegalovirus elicits a coordinated cellular antiviral response via envelope glycoprotein B. J. Virol. 2004, 78, 1202-1211.

20. Simmen, K.A.; Singh, J.; Luukkonen, B.G.; Lopper, M.; Bittner, A.; Miller, N.E.; Jackson, M.R.; Compton, T.; Fruh, K. Global modulation of cellular transcription by human cytomegalovirus is initiated by viral glycoprotein B. Proc. Natl. Acad. Sci. USA 2001, 98, 7140-7145. 
21. Krummenacher, C.; Baribaud, F.; Ponce de Leon, M.; Baribaud, I.; Whitbeck, J.C.; Xu, R.; Cohen, G.H.; Eisenberg, R.J. Comparative usage of herpesvirus entry mediator A and nectin-1 by laboratory strains and clinical isolates of herpes simplex virus. Virology 2004, 322, 286-299.

22. Compaan, D.M.; Gonzalez, L.C.; Tom, I.; Loyet, K.M.; Eaton, D.; Hymowitz, S.G. Attenuating lymphocyte activity: The crystal structure of the BTLA-HVEM complex. J. Biol. Chem. 2005, 280, 39553-39561.

23. Stiles, K.M.; Whitbeck, J.C.; Lou, H.; Cohen, G.H.; Eisenberg, R.J.; Krummenacher, C. Herpes simplex virus glycoprotein D interferes with binding of herpesvirus entry mediator to its ligands through downregulation and direct competition. J. Virol. 2010, 84, 11646-11660.

24. Mizoguchi, A.; Nakanishi, H.; Kimura, K.; Matsubara, K.; Ozaki-Kuroda, K.; Katata, T.; Honda, T.; Kiyohara, Y.; Heo, K.; Higashi, M.; et al. Nectin: An adhesion molecule involved in formation of synapses. J. Cell Biol. 2002, 156, 555-565.

25. Galen, B.; Cheshenko, N.; Tuyama, A.; Ramratnam, B.; Herold, B.C. Access to nectin favors herpes simplex virus infection at the apical surface of polarized human epithelial cells. J. Virol. 2006, 80, 12209-12218.

26. Richart, S.M.; Simpson, S.A.; Krummenacher, C.; Whitbeck, J.C.; Pizer, L.I.; Cohen, G.H.; Eisenberg, R.J.; Wilcox, C.L. Entry of herpes simplex virus type 1 into primary sensory neurons in vitro is mediated by Nectin-1/HveC. J. Virol. 2003, 77, 3307-3311.

27. Simpson, S.A.; Manchak, M.D.; Hager, E.J.; Krummenacher, C.; Whitbeck, J.C.; Levin, M.J.; Freed, C.R.; Wilcox, C.L.; Cohen, G.H.; Eisenberg, R.J.; et al. Nectin-1/HveC Mediates herpes simplex virus type 1 entry into primary human sensory neurons and fibroblasts. J. Neurovirol. 2005, 11, 208-218.

28. Taylor, J.M.; Lin, E.; Susmarski, N.; Yoon, M.; Zago, A.; Ware, C.F.; Pfeffer, K.; Miyoshi, J.; Takai, Y.; Spear, P.G. Alternative entry receptors for herpes simplex virus and their roles in disease. Cell Host Microbe 2007, 2, 19-28.

29. Kopp, S.J.; Banisadr, G.; Glajch, K.; Maurer, U.E.; Grunewald, K.; Miller, R.J.; Osten, P.; Spear, P.G. Infection of neurons and encephalitis after intracranial inoculation of herpes simplex virus requires the entry receptor nectin-1. Proc. Natl. Acad. Sci. USA 2009, 106, 17916-17920.

30. Karaba, A.H.; Kopp, S.J.; Longnecker, R. Herpesvirus entry mediator and nectin-1 mediate herpes simplex virus 1 infection of the murine cornea. J. Virol. 2011, 85, 10041-10047.

31. Geraghty, R.J.; Krummenacher, C.; Cohen, G.H.; Eisenberg, R.J.; Spear, P.G. Entry of alphaherpesviruses mediated by poliovirus receptor-related protein 1 and poliovirus receptor. Science 1998, 280, 1618-1620.

32. Milne, R.S.; Connolly, S.A.; Krummenacher, C.; Eisenberg, R.J.; Cohen, G.H. Porcine HveC, a member of the highly conserved HveC/nectin 1 family, is a functional alphaherpesvirus receptor. Virology 2001, 281, 315-328.

33. Fan, Q.; Amen, M.; Harden, M.; Severini, A.; Griffiths, A.; Longnecker, R. Herpes B virus utilizes human nectin-1 but not HVEM or PILRalpha for cell-cell fusion and virus entry. J. Virol. 2012, 86, 4468-4476.

34. Varthakavi, V.; Minocha, H.C. Identification of a $56 \mathrm{kDa}$ putative bovine herpesvirus 1 cellular receptor by anti-idiotype antibodies. J. Gen. Virol. 1996, 77, 1875-1882. 
35. Cole, N.L.; Grose, C. Membrane fusion mediated by herpesvirus glycoproteins: The paradigm of varicella-zoster virus. Rev. Med. Virol. 2003, 13, 207-222.

36. Li, Q.; Ali, M.A.; Wang, K.; Sayre, D.; Hamel, F.G.; Fischer, E.R.; Bennett, R.G.; Cohen, J.I. Insulin degrading enzyme induces a conformational change in varicella-zoster virus $\mathrm{gE}$, and enhances virus infectivity and stability. PLoS One 2010, 5, e11327.

37. Li, Q.; Ali, M.A.; Cohen, J.I. Insulin degrading enzyme is a cellular receptor mediating varicellazoster virus infection and cell-to-cell spread. Cell 2006, 127, 305-316.

38. Zerboni, L.; Berarducci, B.; Rajamani, J.; Jones, C.D.; Zehnder, J.L.; Arvin, A. Varicella-zoster virus glycoprotein $\mathrm{E}$ is a critical determinant of virulence in the SCID mouse-human model of neuropathogenesis. J. Virol. 2011, 85, 98-111.

39. Cha, T.A.; Tom, E.; Kemble, G.W.; Duke, G.M.; Mocarski, E.S.; Spaete, R.R. Human cytomegalovirus clinical isolates carry at least 19 genes not found in laboratory strains. J. Virol. 1996, 70, 78-83.

40. Ryckman, B.J.; Rainish, B.L.; Chase, M.C.; Borton, J.A.; Nelson, J.A.; Jarvis, M.A.; Johnson, D.C. Characterization of the human cytomegalovirus $\mathrm{gH} / \mathrm{gL} / \mathrm{UL} 128-131$ complex that mediates entry into epithelial and endothelial cells. J. Virol. 2008, 82, 60-70.

41. Ryckman, B.J.; Chase, M.C.; Johnson, D.C. HCMV gH/gL/UL128-131 interferes with virus entry into epithelial cells: Evidence for cell type-specific receptors. Proc. Natl. Acad. Sci. USA 2008, 105, 14118-14123.

42. Ryckman, B.J.; Chase, M.C.; Johnson, D.C. Human cytomegalovirus TR strain glycoprotein O acts as a chaperone promoting $\mathrm{gH} / \mathrm{gL}$ incorporation into virions but is not present in virions. J. Virol. 2010, 84, 2597-2609.

43. Wille, P.T.; Knoche, A.J.; Nelson, J.A.; Jarvis, M.A.; Johnson, D.C. A human cytomegalovirus $\mathrm{gO}-$ null mutant fails to incorporate $\mathrm{gH} / \mathrm{gL}$ into the virion envelope and is unable to enter fibroblasts and epithelial and endothelial cells. J. Virol. 2010, 84, 2585-2596.

44. Vanarsdall, A.L.; Ryckman, B.J.; Chase, M.C.; Johnson, D.C. Human cytomegalovirus glycoproteins $\mathrm{gB}$ and $\mathrm{gH} / \mathrm{gL}$ mediate epithelial cell-cell fusion when expressed either in cis or in trans. J. Virol. 2008, 82, 11837-11850.

45. York, I.A.; Roop, C.; Andrews, D.W.; Riddell, S.R.; Graham, F.L.; Johnson, D.C. A cytosolic herpes simplex virus protein inhibits antigen presentation to CD8+ T lymphocytes. Cell 1994, 77, 525-535.

46. Jugovic, P.; Hill, A.M.; Tomazin, R.; Ploegh, H.; Johnson, D.C. Inhibition of major histocompatibility complex class I antigen presentation in pig and primate cells by herpes simplex virus type 1 and 2 ICP47. J. Virol. 1998, 72, 5076-5084.

47. Tomazin, R.; van Schoot, N.E.; Goldsmith, K.; Jugovic, P.; Sempe, P.; Fruh, K.; Johnson, D.C. Herpes simplex virus type 2 ICP47 inhibits human TAP but not mouse TAP. J. Virol. 1998, 72, 2560-2563.

48. Vanarsdall, A.L.; Chase, M.C.; Johnson, D.C. Human cytomegalovirus glycoprotein gO complexes with $\mathrm{gH} / \mathrm{gL}$, promoting interference with viral entry into human fibroblasts but not entry into epithelial cells. J. Virol. 2011, 85, 11638-11645. 
49. Bentz, G.L.; Yurochko, A.D. Human CMV infection of endothelial cells induces an angiogenic response through viral binding to EGF receptor and beta1 and beta3 integrins. Proc. Natl. Acad. Sci. USA 2008, 105, 5531-5536.

50. Tang, H.; Hayashi, M.; Maeki, T.; Yamanishi, K.; Mori, Y. Human herpesvirus 6 glycoprotein complex formation is required for folding and trafficking of the $\mathrm{gH} / \mathrm{gL} / \mathrm{gQ} 1 / \mathrm{gQ} 2$ complex and its cellular receptor binding. J. Virol. 2011, 85, 11121-11130.

51. Tang, H.; Kawabata, A.; Yoshida, M.; Oyaizu, H.; Maeki, T.; Yamanishi, K.; Mori, Y. Human herpesvirus 6 encoded glycoprotein Q1 gene is essential for virus growth. Virology 2010, 407, 360-367.

52. Turk, S.M.; Hutt-Fletcher, L.M. The Epstein-Barr virus-associated protein p105 is not encoded by the Epstein-Barr virus genome. Virology 1994, 200, 313-318.

53. Turk, S.M.; Jiang, R.; Chesnokova, L.S.; Hutt-Fletcher, L.M. Antibodies to gp350/220 enhance the ability of Epstein-Barr virus to infect epithelial cells. J. Virol. 2006, 80, 9628-9633.

54. Chesnokova, L.S.; Hutt-Fletcher, L.M. Fusion of Epstein-Barr virus with epithelial cells can be triggered by alphavbeta5 in addition to alphavbeta6 and alphavbeta8, and integrin binding triggers a conformational change in glycoproteins gHgL. J. Virol. 2011, 85, 13214-13223.

55. Borza, C.M.; Morgan, A.J.; Turk, S.M.; Hutt-Fletcher, L.M. Use of gHgL for attachment of Epstein-Barr virus to epithelial cells compromises infection. J. Virol. 2004, 78, 5007-5014.

56. Borza, C.M.; Hutt-Fletcher, L.M. Alternate replication in B cells and epithelial cells switches tropism of Epstein-Barr virus. Nat. Med. 2002, 8, 594-599.

57. Mullen, M.M.; Haan, K.M.; Longnecker, R.; Jardetzky, T.S. Structure of the Epstein-Barr virus gp42 protein bound to the MHC class II receptor HLA-DR1. Mol. Cell 2002, 9, 375-385.

58. Kirschner, A.N.; Sorem, J.; Longnecker, R.; Jardetzky, T.S. Structure of Epstein-Barr virus glycoprotein 42 suggests a mechanism for triggering receptor-activated virus entry. Structure 2009, 17, 223-233.

59. Sorem, J.; Jardetzky, T.S.; Longnecker, R. Cleavage and secretion of Epstein-Barr virus glycoprotein 42 promote membrane fusion with B lymphocytes. J. Virol. 2009, 83, 6664-6672.

60. Kirschner, A.N.; Omerovic, J.; Popov, B.; Longnecker, R.; Jardetzky, T.S. Soluble Epstein-Barr virus glycoproteins $\mathrm{gH}, \mathrm{gL}$, and gp42 form a 1:1:1 stable complex that acts like soluble gp42 in B-cell fusion but not in epithelial cell fusion. J. Virol. 2006, 80, 9444-9454.

61. Shaw, P.L.; Kirschner, A.N.; Jardetzky, T.S.; Longnecker, R. Characteristics of Epstein-Barr virus envelope protein gp42. Virus Genes 2010, 40, 307-319.

62. Carfi, A.; Willis, S.H.; Whitbeck, J.C.; Krummenacher, C.; Cohen, G.H.; Eisenberg, R.J.; Wiley, D.C. Herpes simplex virus glycoprotein D bound to the human receptor HveA. Mol. Cell 2001, 8, 169-179.

63. Krummenacher, C.; Supekar, V.M.; Whitbeck, J.C.; Lazear, E.; Connolly, S.A.; Eisenberg, R.J.; Cohen, G.H.; Wiley, D.C.; Carfi, A. Structure of unliganded HSV gD reveals a mechanism for receptor-mediated activation of virus entry. EMBO J. 2005, 24, 4144-4153.

64. Di Giovine, P.; Settembre, E.C.; Bhargava, A.K.; Luftig, M.A.; Lou, H.; Cohen, G.H.; Eisenberg, R.J.; Krummenacher, C.; Carfi, A. Structure of herpes simplex virus glycoprotein D bound to the human receptor nectin-1. PLoS Pathog. 2011, 7, e1002277. 
65. Zhang, N.; Yan, J.; Lu, G.; Guo, Z.; Fan, Z.; Wang, J.; Shi, Y.; Qi, J.; Gao, G.F. Binding of herpes simplex virus glycoprotein D to nectin-1 exploits host cell adhesion. Nat. Commun. 2011, 2, 577.

66. Rux, A.H.; Willis, S.H.; Nicola, A.V.; Hou, W.; Peng, C.; Lou, H.; Cohen, G.H.; Eisenberg, R.J. Functional region IV of glycoprotein D from herpes simplex virus modulates glycoprotein binding to the herpesvirus entry mediator. J. Virol. 1998, 72, 7091-7098.

67. Willis, S.H.; Rux, A.H.; Peng, C.; Whitbeck, J.C.; Nicola, A.V.; Lou, H.; Hou, W.; Salvador, L.; Eisenberg, R.J.; Cohen, G.H. Examination of the kinetics of herpes simplex virus glycoprotein D binding to the herpesvirus entry mediator, using surface plasmon resonance. J. Virol. 1998, 72, 5937-5947.

68. Krummenacher, C.; Rux, A.H.; Whitbeck, J.C.; Ponce-de-Leon, M.; Lou, H.; Baribaud, I.; Hou, W.; Zou, C.; Geraghty, R.J.; Spear, P.G.; et al. The first immunoglobulin-like domain of $\mathrm{HveC}$ is sufficient to bind herpes simplex virus gD with full affinity, while the third domain is involved in oligomerization of HveC. J. Virol. 1999, 73, 8127-8137.

69. Connolly, S.A.; Landsburg, D.J.; Carfi, A.; Wiley, D.C.; Eisenberg, R.J.; Cohen, G.H. Structure-based analysis of the herpes simplex virus glycoprotein D binding site present on herpesvirus entry mediator HveA (HVEM). J. Virol. 2002, 76, 10894-10904.

70. Connolly, S.A.; Landsburg, D.J.; Carfi, A.; Wiley, D.C.; Cohen, G.H.; Eisenberg, R.J. Structure-based mutagenesis of herpes simplex virus glycoprotein D defines three critical regions at the gD-HveA/HVEM binding interface. J. Virol. 2003, 77, 8127-8140.

71. Yoon, M.; Zago, A.; Shukla, D.; Spear, P.G. Mutations in the $\mathrm{N}$ termini of herpes simplex virus type 1 and 2 gDs alter functional interactions with the entry/fusion receptors HVEM, nectin-2, and 3-O-sulfated heparan sulfate but not with nectin-1. J. Virol. 2003, 77, 9221-9231.

72. Cocchi, F.; Menotti, L.; Mirandola, P.; Lopez, M.; Campadelli-Fiume, G. The ectodomain of a novel member of the immunoglobulin subfamily related to the poliovirus receptor has the attributes of a bona fide receptor for herpes simplex virus types 1 and 2 in human cells. J. Virol. 1998, 72, 9992-10002.

73. Krummenacher, C.; Baribaud, I.; Ponce de Leon, M.; Whitbeck, J.C.; Lou, H.; Cohen, G.H.; Eisenberg, R.J. Localization of a binding site for herpes simplex virus glycoprotein D on herpesvirus entry mediator $\mathrm{C}$ by using antireceptor monoclonal antibodies. J. Virol. 2000, 74, 10863-10872.

74. Struyf, F.; Plate, A.E.; Spear, P.G. Deletion of the second immunoglobulin-like domain of nectin-1 alters its intracellular processing and localization and ability to mediate entry of herpes simplex virus. J. Virol. 2005, 79, 3841-3845.

75. Whitbeck, J.C.; Muggeridge, M.I.; Rux, A.; Hou, W.; Krummenacher, C.; Lou, H.; van Geelen, A.; Eisenberg, R.J.; Cohen, G.H. The major neutralizing antigenic site on herpes simplex virus glycoprotein D overlaps a receptor-binding domain. J. Virol. 1999, 73, 9879-9890.

76. Manoj, S.; Jogger, C.R.; Myscofski, D.; Yoon, M.; Spear, P.G. Mutations in herpes simplex virus glycoprotein D that prevent cell entry via nectins and alter cell tropism. Proc. Natl. Acad. Sci. USA 2004, 101, 12414-12421. 
77. Connolly, S.A.; Landsburg, D.J.; Carfi, A.; Whitbeck, J.C.; Zuo, Y.; Wiley, D.C.; Cohen, G.H.; Eisenberg, R.J. Potential nectin-1 binding site on herpes simplex virus glycoprotein d. J. Virol. 2005, 79, 1282-1295.

78. Spear, P.G.; Manoj, S.; Yoon, M.; Jogger, C.R.; Zago, A.; Myscofski, D. Different receptors binding to distinct interfaces on herpes simplex virus gD can trigger events leading to cell fusion and viral entry. Virology 2006, 344, 17-24.

79. Uchida, H.; Shah, W.A.; Ozuer, A.; Frampton, A.R., Jr.; Goins, W.F.; Grandi, P.; Cohen, J.B.; Glorioso, J.C. Generation of herpesvirus entry mediator (HVEM)-restricted herpes simplex virus type 1 mutant viruses: Resistance of HVEM-expressing cells and identification of mutations that rescue nectin-1 recognition. J. Virol. 2009, 83, 2951-2961.

80. Zago, A.; Spear, P.G. Differences in the N termini of herpes simplex virus type 1 and 2 gDs that influence functional interactions with the human entry receptor Nectin-2 and an entry receptor expressed in Chinese hamster ovary cells. J. Virol. 2003, 77, 9695-9699.

81. Jogger, C.R.; Montgomery, R.I.; Spear, P.G. Effects of linker-insertion mutations in herpes simplex virus $1 \mathrm{gD}$ on glycoprotein-induced fusion with cells expressing HVEM or nectin-1. Virology 2004, 318, 318-326.

82. Zago, A.; Jogger, C.R.; Spear, P.G. Use of herpes simplex virus and pseudorabies virus chimeric glycoprotein D molecules to identify regions critical for membrane fusion. Proc. Natl. Acad. Sci. USA 2004, 101, 17498-17503.

83. Narita, H.; Yamamoto, Y.; Suzuki, M.; Miyazaki, N.; Yoshida, A.; Kawai, K.; Iwasaki, K.; Nakagawa, A.; Takai, Y.; Sakisaka, T. Crystal Structure of the cis-Dimer of Nectin-1: Implications for the architecture of cell-cell junctions. J. Biol. Chem. 2011, 286, 12659-12669.

84. Cocchi, F.; Fusco, D.; Menotti, L.; Gianni, T.; Eisenberg, R.J.; Cohen, G.H.; Campadelli-Fiume, G. The soluble ectodomain of herpes simplex virus $\mathrm{gD}$ contains a membrane-proximal pro-fusion domain and suffices to mediate virus entry. Proc. Natl. Acad. Sci. USA 2004, 101, 7445-7450.

85. Heldwein, E.E.; Krummenacher, C. Entry of herpesviruses into mammalian cells. Cell. Mol. Life Sci. 2008, 65, 1653-1668.

86. Lazear, E.; Carfi, A.; Whitbeck, J.C.; Cairns, T.M.; Krummenacher, C.; Cohen, G.H.; Eisenberg, R.J. Engineered disulfide bonds in herpes simplex virus type $1 \mathrm{gD}$ separate receptor binding from fusion initiation and viral entry. J. Virol. 2008, 82, 700-709.

87. Struyf, F.; Martinez, W.M.; Spear, P.G. Mutations in the N-terminal domains of nectin-1 and nectin-2 reveal differences in requirements for entry of various alphaherpesviruses and for nectin-nectin interactions. J. Virol. 2002, 76, 12940-12950.

88. Bogan, A.A.; Thorn, K.S. Anatomy of hot spots in protein interfaces. J. Mol. Biol. 1998, 280, $1-9$.

89. Minson, A.C.; Hodgman, T.C.; Digard, P.; Hancock, D.C.; Bell, S.E.; Buckmaster, E.A. An analysis of the biological properties of monoclonal antibodies against glycoprotein $\mathrm{D}$ of herpes simplex virus and identification of amino acid substitutions that confer resistance to neutralization. J. Gen. Virol. 1986, 67, 1001-1013.

90. Chiang, H.Y.; Cohen, G.H.; Eisenberg, R.J. Identification of functional regions of herpes simplex virus glycoprotein $\mathrm{gD}$ by using linker-insertion mutagenesis. J. Virol. 1994, 68, 2529-2543. 
91. Muggeridge, M.I.; Wu, T.T.; Johnson, D.C.; Glorioso, J.C.; Eisenberg, R.J.; Cohen, G.H. Antigenic and functional analysis of a neutralization site of HSV-1 glycoprotein D. Virology 1990, 174, 375-387.

92. Dix, R.D.; Pereira, L.; Baringer, J.R. Use of monoclonal antibody directed against herpes simplex virus glycoproteins to protect mice against acute virus-induced neurological disease. Infect. Immun. 1981, 34, 192-199.

93. Krummenacher, C.; Nicola, A.V.; Whitbeck, J.C.; Lou, H.; Hou, W.; Lambris, J.D.; Geraghty, R.J.; Spear, P.G.; Cohen, G.H.; Eisenberg, R.J. Herpes simplex virus glycoprotein D can bind to poliovirus receptor-related protein 1 or herpesvirus entry mediator, two structurally unrelated mediators of virus entry. J. Virol. 1998, 72, 7064-7074.

94. Nicola, A.V.; Ponce de Leon, M.; Xu, R.; Hou, W.; Whitbeck, J.C.; Krummenacher, C.; Montgomery, R.I.; Spear, P.G.; Eisenberg, R.J.; Cohen, G.H. Monoclonal antibodies to distinct sites on herpes simplex virus (HSV) glycoprotein D block HSV binding to HVEM. J. Virol. 1998, 72, 3595-3601.

95. Lazear, E.; Whitbeck, J.C.; Ponce-de-Leon, M.; Cairns, T.M.; Willis, S.H.; Zuo, Y.; Krummenacher, C.; Cohen, G.H.; Eisenberg, R.J. Antibody-induced conformational changes in herpes simplex virus glycoprotein gD reveal new targets for virus neutralization. J. Virol. 2012, 86, 1563-1576.

96. Atanasiu, D.; Whitbeck, J.C.; Cairns, T.M.; Reilly, B.; Cohen, G.H.; Eisenberg, R.J. Bimolecular complementation reveals that glycoproteins $\mathrm{gB}$ and $\mathrm{gH} / \mathrm{gL}$ of herpes simplex virus interact with each other during cell fusion. Proc. Natl. Acad. Sci. USA 2007, 104, 18718-18723.

97. Gianni, T.; Amasio, M.; Campadelli-Fiume, G. Herpes simplex virus gD forms distinct complexes with fusion executors $\mathrm{gB}$ and $\mathrm{gH} / \mathrm{gL}$ in part through the $\mathrm{C}$-terminal profusion domain. J. Biol. Chem. 2009, 284, 17370-17382.

98. Peng, T.; Ponce-de-Leon, M.; Jiang, H.; Dubin, G.; Lubinski, J.M.; Eisenberg, R.J.; Cohen, G.H. The gH-gL complex of herpes simplex virus (HSV) stimulates neutralizing antibody and protects mice against HSV type 1 challenge. J. Virol. 1998, 72, 65-72.

99. Macagno, A.; Bernasconi, N.L.; Vanzetta, F.; Dander, E.; Sarasini, A.; Revello, M.G.; Gerna, G.; Sallusto, F.; Lanzavecchia, A. Isolation of human monoclonal antibodies that potently neutralize human cytomegalovirus infection by targeting different epitopes on the gH/gL/UL128-131A complex. J. Virol. 2010, 84, 1005-1013.

100. Buckmaster, E.A.; Gompels, U.; Minson, A. Characterisation and physical mapping of an HSV-1 glycoprotein of approximately 115 X 10(3) molecular weight. Virology 1984, 139, 408-413.

101. Roberts, S.R.; Ponce de Leon, M.; Cohen, G.H.; Eisenberg, R.J. Analysis of the intracellular maturation of the herpes simplex virus type 1 glycoprotein $\mathrm{gH}$ in infected and transfected cells. Virology 1991, 184, 609-624.

102. Hutchinson, L.; Browne, H.; Wargent, V.; Davis-Poynter, N.; Primorac, S.; Goldsmith, K.; Minson, A.C.; Johnson, D.C. A novel herpes simplex virus glycoprotein, gL, forms a complex with glycoprotein $\mathrm{H}(\mathrm{gH})$ and affects normal folding and surface expression of $\mathrm{gH}$. J. Virol. 1992, 66, 2240-2250.

103. Cairns, T.M.; Shaner, M.S.; Zuo, Y.; Ponce de Leon, M.; Baribaud, I.; Eisenberg, R.J.; Cohen, G.H.; Whitbeck, J.C. Epitope mapping of herpes simplex virus type $2 \mathrm{gH} / \mathrm{gL}$ defines 
distinct antigenic sites, including some associated with biological function. J. Virol. 2006, 80, 2596-2608.

104. Roop, C.; Hutchinson, L.; Johnson, D.C. A mutant herpes simplex virus type 1 unable to express glycoprotein L cannot enter cells, and its particles lack glycoprotein H. J. Virol. 1993, 67, 2285-2297.

105. Dubin, G.; Jiang, H. Expression of herpes simplex virus type 1 glycoprotein L (gL) in transfected mammalian cells: Evidence that gL is not independently anchored to cell membranes. J. Virol. 1995, 69, 4564-4568.

106. Peng, T.; Ponce de Leon, M.; Novotny, M.J.; Jiang, H.; Lambris, J.D.; Dubin, G.; Spear, P.G.; Cohen, G.H.; Eisenberg, R.J. Structural and antigenic analysis of a truncated form of the herpes simplex virus glycoprotein gH-gL complex. J. Virol. 1998, 72, 6092-6103.

107. Pertel, P.E. Human herpesvirus 8 glycoprotein $\mathrm{B}(\mathrm{gB})$, gH, and gL can mediate cell fusion. J. Virol. 2002, 76, 4390-4400.

108. Kinzler, E.R.; Compton, T. Characterization of human cytomegalovirus glycoprotein-induced cell-cell fusion. J. Virol. 2005, 79, 7827-7837.

109. Subramanian, R.P.; Geraghty, R.J. Herpes simplex virus type 1 mediates fusion through a hemifusion intermediate by sequential activity of glycoproteins D, H, L, and B. Proc. Natl. Acad. Sci. USA 2007, 104, 2903-2908.

110. Jackson, J.O.; Longnecker, R. Reevaluating herpes simplex virus hemifusion. J. Virol. 2010, 84, 11814-11821.

111. Pasieka, T.J.; Maresova, L.; Shiraki, K.; Grose, C. Regulation of varicella-zoster virus-induced cell-to-cell fusion by the endocytosis-competent glycoproteins $\mathrm{gH}$ and $\mathrm{gE}$. J. Virol. 2004, 78, 2884-2896.

112. Lopper, M.; Compton, T. Coiled-coil domains in glycoproteins B and H are involved in human cytomegalovirus membrane fusion. J. Virol. 2004, 78, 8333-8341.

113. Gianni, T.; Piccoli, A.; Bertucci, C.; Campadelli-Fiume, G. Heptad repeat 2 in herpes simplex virus $1 \mathrm{gH}$ interacts with heptad repeat 1 and is critical for virus entry and fusion. J. Virol. 2006, 80, 2216-2224.

114. Galdiero, S.; Falanga, A.; Vitiello, M.; D’Isanto, M.; Collins, C.; Orrei, V.; Browne, H.; Pedone, C.; Galdiero, M. Evidence for a role of the membrane-proximal region of herpes simplex virus type 1 glycoprotein h in membrane fusion and virus inhibition. Chem. Biochem. 2007, 8, 885-895.

115. Galdiero, S.; Falanga, A.; Vitiello, M.; D’Isanto, M.; Cantisani, M.; Kampanaraki, A.; Benedetti, E.; Browne, H.; Galdiero, M. Peptides containing membrane-interacting motifs inhibit herpes simplex virus type 1 infectivity. Peptides 2008, 29, 1461-1471.

116. Galdiero, S.; Vitiello, M.; D’Isanto, M.; Falanga, A.; Collins, C.; Raieta, K.; Pedone, C.; Browne, H.; Galdiero, M. Analysis of synthetic peptides from heptad-repeat domains of herpes simplex virus type 1 glycoproteins H and B. J. Gen. Virol. 2006, 87, 1085-1097.

117. Bender, F.C.; Whitbeck, J.C.; Ponce de Leon, M.; Lou, H.; Eisenberg, R.J.; Cohen, G.H. Specific association of glycoprotein B with lipid rafts during herpes simplex virus entry. J. Virol. 2003, 77, 9542-9552. 
118. Cairns, T.M.; Whitbeck, J.C.; Lou, H.; Heldwein, E.E.; Chowdary, T.K.; Eisenberg, R.J.; Cohen, G.H. Capturing the herpes simplex virus core fusion complex (gB-gH/gL) in an acidic environment. J. Virol. 2011, 85, 6175-6184.

119. Chowdary, T.K.; Cairns, T.M.; Atanasiu, D.; Cohen, G.H.; Eisenberg, R.J.; Heldwein, E.E. Crystal structure of the conserved herpesvirus fusion regulator complex gH-gL. Nat. Struct. Mol. Biol. 2010, 17, 882-888.

120. Backovic, M.; DuBois, R.M.; Cockburn, J.J.; Sharff, A.J.; Vaney, M.C.; Granzow, H.; Klupp, B.G.; Bricogne, G.; Mettenleiter, T.C.; Rey, F.A. Structure of a core fragment of glycoprotein $\mathrm{H}$ from pseudorabies virus in complex with antibody. Proc. Natl. Acad. Sci. USA 2010, 107, 22635-22640.

121. Matsuura, H.; Kirschner, A.N.; Longnecker, R.; Jardetzky, T.S. Crystal structure of the Epstein-Barr virus (EBV) glycoprotein H/glycoprotein L (gH/gL) complex. Proc. Natl. Acad. Sci. USA 2010, 107, 22641-22646.

122. Grunewald, K.; Desai, P.; Winkler, D.C.; Heymann, J.B.; Belnap, D.M.; Baumeister, W.; Steven, A.C. Three-dimensional structure of herpes simplex virus from cryo-electron tomography. Science 2003, 302, 1396-1398.

123. Harrison, S.C. Viral membrane fusion. Nat. Struct. Mol. Biol. 2008, 15, 690-698.

124. Kielian, M.; Rey, F.A. Virus membrane-fusion proteins: More than one way to make a hairpin. Nat. Rev. Microbiol. 2006, 4, 67-76.

125. Backovic, M.; Jardetzky, T.S. Class III viral membrane fusion proteins. Curr. Opin. Struct. Biol. 2009, 19, 189-196.

126. Gianni, T.; Fato, R.; Bergamini, C.; Lenaz, G.; Campadelli-Fiume, G. Hydrophobic alpha-helices 1 and 2 of herpes simplex virus $\mathrm{gH}$ interact with lipids, and their mimetic peptides enhance virus infection and fusion. J. Virol. 2006, 80, 8190-8198.

127. Gompels, U.A.; Craxton, M.A.; Honess, R.W. Conservation of glycoprotein H (gH) in herpesviruses: Nucleotide sequence of the gH gene from herpesvirus saimiri. J. Gen. Virol. 1988, 69, 2819-2829.

128. Galdiero, M.; Whiteley, A.; Bruun, B.; Bell, S.; Minson, T.; Browne, H. Site-Directed and linker Insertion Mutangenesis of Herpes Simplex Virus Type 1 Glycoprotein H. J. Virol. 1997, 71, 2163-2170.

129. Wu, L.; Borza, C.M.; Hutt-Fletcher, L.M. Mutations of Epstein-Barr virus gH that are differentially able to support fusion with B cells or epithelial cells. J. Virol. 2005, 79, 10923-10930.

130. Vleck, S.E.; Oliver, S.L.; Brady, J.J.; Blau, H.M.; Rajamani, J.; Sommer, M.H.; Arvin, A.M. Structure-function analysis of varicella-zoster virus glycoprotein $\mathrm{H}$ identifies domain-specific roles for fusion and skin tropism. Proc. Natl. Acad. Sci. USA 2011, 108, 18412-18417.

131. Gompels, U.A.; Carss, A.L.; Saxby, C.; Hancock, D.C.; Forrester, A.; Minson, A.C. Characterization and sequence analyses of antibody-selected antigenic variants of herpes simplex virus show a conformationally complex epitope on glycoprotein H. J. Virol. 1991, 65, 2393-2401.

132. Omerovic, J.; Lev, L.; Longnecker, R. The amino terminus of Epstein-Barr virus glycoprotein gH is important for fusion with epithelial and B cells. J. Virol. 2005, 79, 12408-12415. 
133. Plate, A.E.; Smajlovic, J.; Jardetzky, T.S.; Longnecker, R. Functional analysis of glycoprotein L $(\mathrm{gL})$ from rhesus lymphocryptovirus in Epstein-Barr virus-mediated cell fusion indicates a direct role of gL in gB-induced membrane fusion. J. Virol. 2009, 83, 7678-7689.

134. Atanasiu, D.; Whitbeck, J.C.; de Leon, M.P.; Lou, H.; Hannah, B.P.; Cohen, G.H.; Eisenberg, R.J. Bimolecular complementation defines functional regions of Herpes simplex virus $\mathrm{gB}$ that are involved with $\mathrm{gH} / \mathrm{gL}$ as a necessary step leading to cell fusion. J. Virol. 2010, 84, 3825-3834.

135. Cairns, T.M.; Friedman, L.S.; Lou, H.; Whitbeck, J.C.; Shaner, M.S.; Cohen, G.H.; Eisenberg, R.J. $\mathrm{N}$-terminal mutants of herpes simplex virus type $2 \mathrm{gH}$ are transported without $\mathrm{gL}$ but require $\mathrm{gL}$ for function. J. Virol. 2007, 81, 5102-5111.

136. Avitabile, E.; Forghieri, C.; Campadelli-Fiume, G. Complexes between herpes simplex virus glycoproteins $\mathrm{gD}, \mathrm{gB}$, and $\mathrm{gH}$ detected in cells by complementation of split enhanced green fluorescent protein. J. Virol. 2007, 81, 11532-11537.

137. Parry, C.; Bell, S.; Minson, T.; Browne, H. Herpes simplex virus type 1 glycoprotein $H$ binds to alphavbeta3 integrins. J. Gen. Virol. 2005, 86, 7-10.

138. Gianni, T.; Cerretani, A.; Dubois, R.; Salvioli, S.; Blystone, S.S.; Rey, F.; Campadelli-Fiume, G. Herpes simplex virus glycoproteins $\mathrm{H} / \mathrm{L}$ bind to cells independently of $\{$ alpha $\} \mathrm{V}\{$ beta 3 integrin and inhibit virus entry, and their constitutive expression restricts infection. J. Virol. 2010, 84, 4013-4025.

139. Roche, S.; Albertini, A.A.; Lepault, J.; Bressanelli, S.; Gaudin, Y. Structures of vesicular stomatitis virus glycoprotein: Membrane fusion revisited. Cell. Mol. Life Sci. 2008, 65, 1716-1728.

140. Diederich, S.; Dietzel, E.; Maisner, A. Nipah virus fusion protein: Influence of cleavage site mutations on the cleavability by cathepsin L, trypsin and furin. Virus Res. 2009, 145, 300-306.

141. Diederich, S.; Moll, M.; Klenk, H.D.; Maisner, A. The nipah virus fusion protein is cleaved within the endosomal compartment. J. Biol. Chem. 2005, 280, 29899-29903.

142. Bzik, D.J.; Fox, B.A.; DeLuca, N.A.; Person, S. Nucleotide sequence of a region of the herpes simplex virus type $1 \mathrm{gB}$ glycoprotein gene: Mutations affecting rate of virus entry and cell fusion. Virology 1984, 137, 185-190.

143. Heldwein, E.E.; Lou, H.; Bender, F.C.; Cohen, G.H.; Eisenberg, R.J.; Harrison, S.C. Crystal structure of glycoprotein B from herpes simplex virus 1. Science 2006, 313, 217-220.

144. Roche, S.; Bressanelli, S.; Rey, F.A.; Gaudin, Y. Crystal structure of the low-pH form of the vesicular stomatitis virus glycoprotein G. Science 2006, 313, 187-191.

145. Kadlec, J.; Loureiro, S.; Abrescia, N.G.; Stuart, D.I.; Jones, I.M. The postfusion structure of baculovirus gp64 supports a unified view of viral fusion machines. Nat. Struct. Mol. Biol. 2008, 15, 1024-1030.

146. Stannard, L.M.; Fuller, A.O.; Spear, P.G. Herpes simplex virus glycoproteins associated with different morphological entities projecting from the virion envelope. J. Gen. Virol. 1987, 68, 715-725.

147. Backovic, M.; Jardetzky, T.S.; Longnecker, R. Hydrophobic residues that form putative fusion loops of Epstein-Barr virus glycoprotein B are critical for fusion activity. J. Virol. 2007, 81, 9596-9600.

148. Hannah, B.P.; Heldwein, E.E.; Bender, F.C.; Cohen, G.H.; Eisenberg, R.J. Mutational evidence of internal fusion loops in herpes simplex virus glycoprotein B. J. Virol. 2007, 81, 4858-4865. 
149. Hannah, B.P.; Cairns, T.M.; Bender, F.C.; Whitbeck, J.C.; Lou, H.; Eisenberg, R.J.; Cohen, G.H. Herpes simplex virus glycoprotein B associates with target membranes via its fusion loops. J. Virol. 2009, 83, 6825-6836.

150. Wright, C.C.; Wisner, T.W.; Hannah, B.P.; Eisenberg, R.J.; Cohen, G.H.; Johnson, D.C. Fusion between perinuclear virions and the outer nuclear membrane requires the fusogenic activity of herpes simplex virus gB. J. Virol. 2009, 83, 11847-11856.

151. Roche, S.; Rey, F.A.; Gaudin, Y.; Bressanelli, S. Structure of the prefusion form of the vesicular stomatitis virus glycoprotein G. Science 2007, 315, 843-848.

152. Dollery, S.J.; Wright, C.C.; Johnson, D.C.; Nicola, A.V. Low-pH-dependent changes in the conformation and oligomeric state of the prefusion form of herpes simplex virus glycoprotein B are separable from fusion activity. J. Virol. 2011, 85, 9964-9973.

153. Stampfer, S.D.; Lou, H.; Cohen, G.H.; Eisenberg, R.J.; Heldwein, E.E. Structural basis of local, $\mathrm{pH}$-dependent conformational changes in glycoprotein B from herpes simplex virus type 1. J. Virol. 2010, 84, 12924-12933.

154. Backovic, M.; Longnecker, R.; Jardetzky, T.S. Structure of a trimeric variant of the Epstein-Barr virus glycoprotein B. Proc. Natl. Acad. Sci. USA 2009, 106, 2880-2885.

155. Sorem, J.; Longnecker, R. Cleavage of Epstein-Barr virus glycoprotein B is required for full function in cell-cell fusion with both epithelial and B cells. J. Gen. Virol. 2009, 90, 591-595.

156. Kopp, A.; Blewett, E.; Misra, V.; Mettenleiter, T.C. Proteolytic cleavage of bovine herpesvirus 1 $(\mathrm{BHV}-1)$ glycoprotein $\mathrm{gB}$ is not necessary for its function in BHV-1 or pseudorabies virus. J. Virol. 1994, 68, 1667-1674.

157. Kousoulas, K.G.; Pellett, P.E.; Pereira, L.; Roizman, B. Mutations affecting conformation or sequence of neutralizing epitopes identified by reactivity of viable plaques segregate from syn and ts domains of HSV-1(F) gB gene. Virology 1984, 135, 379-394.

158. Cai, W.Z.; Person, S.; Warner, S.C.; Zhou, J.H.; DeLuca, N.A. Linker-insertion nonsense and restriction-site deletion mutations of the $\mathrm{gB}$ glycoprotein gene of herpes simplex virus type 1. J. Virol. 1987, 61, 714-721.

159. Laquerre, S.; Anderson, D.B.; Argnani, R.; Glorioso, J.C. Herpes simplex virus type 1 glycoprotein B requires a cysteine residue at position 633 for folding, processing, and incorporation into mature infectious virus particles. J. Virol. 1998, 72, 4940-4949.

160. Lin, E.; Spear, P.G. Random linker-insertion mutagenesis to identify functional domains of herpes simplex virus type 1 glycoprotein B. Proc. Natl. Acad. Sci. USA 2007, 104, 13140-13145.

161. Arii, J.; Wang, J.; Morimoto, T.; Suenaga, T.; Akashi, H.; Arase, H.; Kawaguchi, Y. A single-amino-acid substitution in herpes simplex virus 1 envelope glycoprotein $\mathrm{B}$ at a site required for binding to the paired immunoglobulin-like type 2 receptor alpha (PILRalpha) abrogates PILRalpha-dependent viral entry and reduces pathogenesis. J. Virol. 2010, 84, 10773-10783.

162. Fan, Q.; Lin, E.; Satoh, T.; Arase, H.; Spear, P.G. Differential effects on cell fusion activity of mutations in herpes simplex virus 1 glycoprotein $\mathrm{B}(\mathrm{gB})$ dependent on whether a $\mathrm{gD}$ receptor or a $\mathrm{gB}$ receptor is overexpressed. J. Virol. 2009, 83, 7384-7390.

163. Backovic, M.; Leser, G.P.; Lamb, R.A.; Longnecker, R.; Jardetzky, T.S. Characterization of EBV gB indicates properties of both class I and class II viral fusion proteins. Virology 2007, 368, 102-113. 
164. Oliver, S.L.; Sommer, M.; Zerboni, L.; Rajamani, J.; Grose, C.; Arvin, A.M. Mutagenesis of varicella-zoster virus glycoprotein B: Putative fusion loop residues are essential for viral replication, and the furin cleavage motif contributes to pathogenesis in skin tissue in vivo. J. Virol. 2009, 83, 7495-7506.

165. Highlander, S.L.; Cai, W.; Person, S.; Levine, M.; Glorioso, J.C. Monoclonal antibodies define a domain on herpes simplex virus glycoprotein B involved in virus penetration. J. Virol. 1988, 62, 1881-1888.

166. Kousoulas, K.G.; Huo, B.; Pereira, L. Antibody-resistant mutations in cross-reactive and type-specific epitopes of herpes simplex virus 1 glycoprotein B map in separate domains. Virology 1988, 166, 423-431.

167. Pereira, L.; Ali, M.; Kousoulas, K.; Huo, B.; Banks, T. Domain structure of herpes simplex virus 1 glycoprotein B: Neutralizing epitopes map in regions of continuous and discontinuous residues. Virology 1989, 172, 11-24.

168. Bender, F.C.; Samanta, M.; Heldwein, E.E.; de Leon, M.P.; Bilman, E.; Lou, H.; Whitbeck, J.C.; Eisenberg, R.J.; Cohen, G.H. Antigenic and mutational analyses of herpes simplex virus glycoprotein B reveal four functional regions. J. Virol. 2007, 81, 3827-3841.

169. Bender, F.C.; Whitbeck, J.C.; Lou, H.; Cohen, G.H.; Eisenberg, R.J. Herpes simplex virus glycoprotein B binds to cell surfaces independently of heparan sulfate and blocks virus entry. J. Virol. 2005, 79, 11588-11597.

170. Satoh, T.; Arase, H. HSV-1 infection through inhibitory receptor, PILRalpha. Uirusu 2008, 58, 27-36.

171. Satoh, T.; Arii, J.; Suenaga, T.; Wang, J.; Kogure, A.; Uehori, J.; Arase, N.; Shiratori, I.; Tanaka, S.; Kawaguchi, Y.; et al. PILRalpha is a herpes simplex virus-1 entry coreceptor that associates with glycoprotein B. Cell 2008, 132, 935-944.

172. Fuller, A.O.; Santos, R.E.; Spear, P.G. Neutralizing antibodies specific for glycoprotein H of herpes simplex virus permit viral attachment to cells but prevent penetration. J. Virol. 1989, 63, 3435-3443.

173. Avitabile, E.; Forghieri, C.; Campadelli-Fiume, G. Cross talking among the glycoproteins involved in herpes simplex virus entry and fusion: The interaction between $\mathrm{gB}$ and $\mathrm{gH} / \mathrm{gL}$ does not necessarily require gD. J. Virol. 2009, 83, 10752-10760.

174. Hu, C.D.; Chinenov, Y.; Kerppola, T.K. Visualization of interactions among bZIP and Rel family proteins in living cells using bimolecular fluorescence complementation. Mol. Cell 2002, 9, 789-798.

175. Kerppola, T.K. Design and implementation of bimolecular fluorescence complementation (BiFC) assays for the visualization of protein interactions in living cells. Nat. Protoc. 2006, 1, 1278-1286.

176. Kerppola, T.K. Bimolecular fluorescence complementation: Visualization of molecular interactions in living cells. Methods Cell Biol. 2008, 85, 431-470.

177. Ventura, S. Bimolecular fluorescence complementation: Illuminating cellular protein interactions. Curr. Mol. Med. 2010, 11, 582-598.

178. Hu, C.D.; Kerppola, T.K. Simultaneous visualization of multiple protein interactions in living cells using multicolor fluorescence complementation analysis. Nat. Biotechnol. 2003, 21, 539-545. 
179. Kerppola, T.K. Visualization of molecular interactions using bimolecular fluorescence complementation analysis: Characteristics of protein fragment complementation. Chem. Soc. Rev. 2009, 38, 2876-2886.

180. Gompels, U.; Minson, A. The properties and sequence of glycoprotein H of herpes simplex virus type 1. Virology 1986, 153, 230-247.

181. Browne, H.M.; Bruun, B.C.; Minson, A.C. Characterization of herpes simplex virus type 1 recombinants with mutations in the cytoplasmic tail of glycoprotein H. J. Gen. Virol. 1996, 77, 2569-2573.

182. Davis-Poynter, N.; Bell, S.; Minson, T.; Browne, H. Analysis of the contributions of herpes simplex virus type 1 membrane proteins to the induction of cell-cell fusion. $J$. Virol. 1994, 68, 7586-7590.

183. Harman, A.; Browne, H.; Minson, T. The transmembrane domain and cytoplasmic tail of herpes simplex virus type 1 glycoprotein H play a role in membrane fusion. $J$. Virol. 2002, 76, 10708-10716.

184. Atanasiu, D.; Saw, W.T.; Cohen, G.H.; Eisenberg, R.J. Cascade of events governing cell-cell fusion induced by herpes simplex virus glycoproteins gD, gH/gL, and gB. J. Virol. 2010, 84, 12292-12299.

185. Browne, H.; Bruun, B.; Minson, T. Plasma membrane requirements for cell fusion induced by herpes simplex virus type 1 glycoproteins gB, gD, gH and gL. J. Gen. Virol. 2001, 82, 1419-1422.

186. Pertel, P.E.; Fridberg, A.; Parish, M.L.; Spear, P.G. Cell fusion induced by herpes simplex virus glycoproteins $\mathrm{gB}, \mathrm{gD}$, and $\mathrm{gH}-\mathrm{gL}$ requires a $\mathrm{gD}$ receptor but not necessarily heparan sulfate. Virology 2001, 279, 313-324.

187. Kirschner, A.N.; Lowrey, A.S.; Longnecker, R.; Jardetzky, T.S. Binding-site interactions between Epstein-Barr virus fusion proteins gp42 and $\mathrm{gH} / \mathrm{gL}$ reveal a peptide that inhibits both epithelial and B-cell membrane fusion. J. Virol. 2007, 81, 9216-9229.

188. Liu, F.; Marquardt, G.; Kirschner, A.N.; Longnecker, R.; Jardetzky, T.S. Mapping the N-terminal residues of Epstein-Barr virus gp42 that bind $\mathrm{gH} / \mathrm{gL}$ by using fluorescence polarization and cell-based fusion assays. J. Virol. 2010, 84, 10375-10385.

189. Heldwein, E.E. Entry of herpesviruses into cells: More than one way to pull the trigger. Structure 2009, 17, 147-149.

190. Connolly, S.A.; Leser, G.P.; Yin, H.S.; Jardetzky, T.S.; Lamb, R.A. Refolding of a paramyxovirus $\mathrm{F}$ protein from prefusion to postfusion conformations observed by liposome binding and electron microscopy. Proc. Natl. Acad. Sci. USA 2006, 103, 17903-17908.

191. Smith, E.C.; Popa, A.; Chang, A.; Masante, C.; Dutch, R.E. Viral entry mechanisms: The increasing diversity of paramyxovirus entry. FEBS J. 2009, 276, 7217-7227.

192. Lee, B.; Ataman, Z.A. Modes of paramyxovirus fusion: A Henipavirus perspective. Trends Microbiol. 2011, 19, 389-399.

193. Dutch, R.E. Entry and fusion of emerging paramyxoviruses. PLoS Pathog. 2010, 6, e1000881.

194. Lee, B.; Ataman, Z.A.; Jin, L. Evil versus 'eph-ective' use of ephrin-B2. Nat. Struct. Mol. Biol. 2008, $15,540-542$.

(C) 2012 by the authors; licensee MDPI, Basel, Switzerland. This article is an open access article distributed under the terms and conditions of the Creative Commons Attribution license (http://creativecommons.org/licenses/by/3.0/). 